Est Ag 40 (2005) 99-144

\title{
Algunos aspectos de la educación
}

\section{EL CAMPO LÉXICO DE LA EDUCACIÓN}

Son varias las palabras con que se designa la educación, algunas muy en boga, otras ya en franco desuso. Las más usadas son: crianza, urbanidad, cortesía, adoctrinamiento, instrucción, enseñanza, educación, formación, acompañamiento, aprendizaje...

Crianza nos retrotrae a los clásicos. Se refiere, sobre todo, a la alimentación de los niños por las madres o nodrizas durante la lactancia. Fray Luis de León, coincidiendo con los tratadistas del matrimonio en el Renacimiento, habla de la obligación que tiene la madre de criar al hijo para traspasarle con la leche al cuerpo sus virtudes e imprimírselas "en el alma tierna de él con los ojos y con los semblantes"1. La crianza se refiere también a la urbanidad o cortesía. Se habla de buena o mala crianza.

Urbanidad y cortesía, dos valores en baja, se refieren a las buenas maneras o modales en el trato social. "Sentimos la cortesía como más afectuosa, y por esto nos halaga más ser tratados con cortesía que con simple urbanidad"2. ¡Cuánto ganaríamos todos si las buenas maneras, no las toscas y asilvestradas, rigieran nuestras relaciones! El trato afable, respetuoso, delicado y cordial humaniza al que lo da y al que lo recibe, los aleja de la selva, los hace más humanos. ¿Hay mejor espiritualidad?

Adoctrinamiento lleva consigo un rasgo de imposición insistente y pertinaz de una doctrina. El que adoctrina inculca con ahínco algo como indiscutible, determinadas ideas y creencias, sin opción a la discrepancia. Ha sido la forma de enseñanza más usual en la historia. La palabra tiene hoy, con razón, mala prensa. Nadie se atreve a usarla sino como condenación;

1. La perfecta casada, edición de Javier San José Lera, Espasa-Calpe, Madrid 1992, XVII, 192.

2. Samuel GILI GAYA, Diccionario de sinónimos, Publicaciones y Ediciones Spes, Barcelona 1961, s. v. urbanidad. 
pero lo significado por ella está lejos de haber desaparecido de las prácticas al uso. Sectas, partidos, iglesias, congregaciones religiosas, asociaciones de todo tipo siguen adoctrinando a más y mejor.

Instrucción denota los conocimientos adquiridos por uno mismo o recibidos de un maestro, o el conjunto de reglas para ejecutar algo. Enseñanza, como instrucción, se refiere a lo intelectual, pero añade la relación a un maestro. Nadie se enseña a sí mismo. Es otra persona quien le enseña, o la experiencia. Quien tiene conocimientos es un hombre instruido (no se dice cómo los ha adquirido), pero no un hombre enseñado ${ }^{3}$. En la enseñan$z a$, alguien transmite a alguien un conocimiento 4 .

Educación está emparentada con ducere, 'guiar', 'dirigir'. El alumno es dirigido por el maestro. Viene de educere, 'extraer', 'sacar fuera'. Se supone que el hombre nace hecho, totalmente hecho, aunque en miniatura, en germen, en semilla. Con el tiempo se irá desarrollando y haciendo visible lo que en el embrión está invisible. "En el semen está comprendida la razón [la razón seminal] de todo lo que será el hombre futuro, y nace la barba y el cabello encanece en virtud de una ley que rige desde el embrión, pues dentro de él se hallan invisibles y en miniatura el cuerpo entero y sus fases sucesivas"'.

No son estas ideas solo del pasado. Incluso hoy hay quienes ponen el acento en los factores genéticos, como si en ellos estuvieran ya las funciones mentales, como si una mente diminuta estuviera ya en las células desde el primer momento. Pero ¿qué se quiere decir con ello? Si lo que se quiere decir es que las facultades están en el embrión en potencia, es decir mucho y no es decir nada. También en el bloque de mármol del que Miguel Ángel hizo el David estaba éste en potencia, pero estaban igualmente otras muchas creaciones artísticas que nunca llegaron a existir. Sin Miguel Ángel, aquel trozo de mármol nunca hubiera llegado a ser el David que todos admiramos. David estaba en potencia en aquel trozo de mármol, se dirá. Bueno, y ¿qué? Lo que nunca se podrá decir es que estaba en él en miniatura, o que en él había oculta una forma esperando que la mano de un artista la hiciera visible, como decían los neoplatónicos en el Renacimiento. Como no es verdad que en el arpa estén dormidas las notas "esperando la mano de nieve que sepa arrancarlas", o que el genio "duerma en el fondo del alma" esperando la voz

3. Cf. Id., îb., s. v.instrucción.

4. Sobre su fórmula semántica, cf. Juan MATEOS, Método de análisis semántico aplicado al griego del Nuevo Testamento, Ediciones El Almendro, Córdoba 1989, 27-29 y 114.

5. SÉNECA, Cuestiones naturales 3, 29. 
que lo despierte 6 . Si entendemos literalmente las metáforas, destruimos su halo poético y la verdad profunda del poema. Las cosas son mucho más complejas, y la mano de nieve que arranca las notas y la voz que hace levantarse al genio necesitan años y años de preparación y mucha sabiduría. Las facultades mentales no están en el embrión en miniatura, como en el padre no están en miniatura sus hijos con todas sus piezas y detalles, encajados unos en otros como muñecas rusas, ni en Adán estábamos todos en miniatura, suponiendo que Adán fuera el primer hombre como se decía en otros tiempos 7 . Su aparición y desarrollo dependen de una serie muy compleja de factores. "Al iniciarse la embriología científica, resultó evidente que la célula germinal no contiene un homúnculo comprimido, sino solamente un plan que requiere la interacción de otros elementos a fin de convertirse en un ser humano"8.

Todos recordamos la mayéutica socrática. Hay en el hombre, innatas, una serie de nociones: la noción de justicia, del bien, de la belleza, las nociones matemáticas... Innatas o aprendidas en una vida anterior. Conocer sería en este último caso recordar. El educador es como una comadrona: ayuda al educando a que dé a luz esas nociones, a que las vaya descubriendo en él mismo. Durante siglos estuvo vigente esta noción de las semillas latentes en el alma. La educación consistía en hacer germinar las semillas de las virtudes y en sofocar, y aun extirpar, las de los vicios. Todo está en germen dentro de nosotros. La tarea del educador consiste en ayudar a que aparezca y se desarrolle lo que en el educando es sólo semilla. "Yo pienso que las virtudes morales en nosotros no sean naturales totalmente, porque ninguna cosa se puede jamás acostumbrar a lo que naturalmente le es contrario [...]. Tampoco se ha de decir que son naturales los vicios totalmente, porque si lo fuesen no tendríamos remedio para ser virtuosos [...]. Como en las otras artes, así también en las virtudes es necesario tener maestro, el cual con su doctrina y buenos consejos despierte y levante en nosotros aquellas virtudes morales, de las cuales tenemos la simiente enterrada en nuestras almas, y las granjee como buen labrador, y les abra el camino por donde nazcan, quitándoles las espinas y las malas hierbas de los deseos, los cuales muchas veces tanto ocupan y ahogan nuestros corazones que ni les dejan echar flor ni producir aquellos singulares frutos que

6. Gustavo Adolfo Bécquer, Rimas y declaraciones poéticas, edición de Francisco López Estrada - Ma . Teresa López García-Berdoy, Espasa-Calpe, Madrid $1989^{4}, 100$.

7. Cf. François JАСOB, La lógica de lo viviente, Editorial Laia, Barcelona 19772, 63-85.

8. José Manuel RoDRíGUEZ DELGADO, Control físico de la mente, Espasa-Calpe, Madrid 1972, 56; ÍD., La mente del niño. Cómo se forma y cómo hay que educarla, Aguilar, Madrid 2001. 
deberíamos desear que naciesen solos en nosotros. Así que de esta manera es natural en los hombres la justicia y la vergüenza [...]. La raíz de estas virtudes, potencialmente engendradas en nuestras almas, si no es ayudada con la doctrina y arte, pierde muchas veces su fuerza y viene a ser tanto como nada". Andan todavía por ahí, resistentes al paso de los siglos, los "gérmenes vocacionales", las semillas depositadas por Dios en algunas personas elegidas desde toda la eternidad para ser sus ministros o para ingresar en determinada Orden religiosa. No con la frecuencia de otros tiempos, pero todavía se lee esta expresión.

Innatismo es también, en última instancia, el iluminismo. Conocer es recibir iluminaciones, ver las ideas y los valores en la luz inmutable del sol del espíritu, que es Dios. San Agustín defendió en un principio la reminiscencia: conocer es recordar. Posteriormente abandonó esta teoría y defendió el iluminismo. La verdad -dos y dos son cuatro, esto es justo y aquello injusto, hay que hacer el bien y evitar el mal...- es puramente inteligible, necesaria, inmutable y eterna. No puede provenir de los objetos ni tampoco de nosotros. Unos y otros somos contingentes, temporales y mudables. "Dios, por el que fueron hechas todas las cosas, es la luz de las mentes en la que aprendemos todo"10. "Lo que percibimos por la razón lo vemos presente en la luz interior de la Verdad con la que es iluminado y de la que goza el hombre interior"11. Lo mismo que el ojo ve, iluminadas por la luz, las cosas que están a su alrededor, así la razón "ve las realidades inteligibles del orden natural en una luz incorpórea especial"12. "Una sola es la Verdad por la que son iluminadas las almas santas, pero como hay muchas almas, se puede decir que hay en ellas muchas verdades, como de un solo rostro aparecen muchas imágenes en los espejos”13. “¿Dónde, oh Verdad, no caminaste conmigo enseñándome qué debo evitar y qué debo apetecer[...]. Entré en los penetrales de mi memoria [...]. Nada pude discernir en ellos sin Ti [...]. Tú eres la luz que permanece, con la que yo consultaba acerca de todas las cosas, si eran, qué eran, en cuanta estima había que tenerlas, y te escuchaba a Ti, que me enseñabas y mandabas. Y esto es lo que hago ahora muchas veces, esto es lo que me deleita, y siempre que puedo librarme de los quehaceres necesarios, me refugio en este gozo"14.

9. Baltasar de CASTIGLIONE, El cortesano, introducción y notas de Rogelio Reyes Cano, Espasa-Calpe, Madrid 19845, IV, 306-307.

10. San Agustín, La ciudad de Dios 8, 7.

11. ÍD., El maestro $12,40$.

12.ÍD., La Trinidad 12, 15, 24.

13. ÍD., Comentarios a los salmos 11, 2. 
Esta es la luz que Agustín descubrió leyendo a los neoplatónicos. "Amonestado por ellos a que volviera a mí mismo, entré en mi interior guiado por Ti. Lo pude hacer porque Tú me ayudaste. Entré y vi con el ojo de mi alma, tal como este es, sobre el mismo ojo de mi alma, sobre mi mente, una luz inmutable. No era esta vulgar y visible a toda carne, no era ésta aquella luz sino cosa muy distinta. No estaba sobre mi mente, como el aceite encima del agua, sino que estaba sobre mí por haberme hecho, y yo estaba debajo de ella porque soy hechura suya. Quien conoce la verdad conoce esta luz y quien la conoce conoce la eternidad. La caridad es quien la conoce [..]. Cuando por primera vez te conocí, Tú me levantaste a Ti para que viera que había algo que ver y que yo aún no era capaz de ver. La vehemencia de tu rayo reverberó en mi débil mirada y me estremecí de amor y de horror"15. "Pues buscando de dónde estimaba yo la hermosura de los cuerpos, ya celestes, ya terrestres, y qué había en mí al juzgar rápida y exactamente de las cosas mudables cuando decía: Esto debe ser así, aquello no; buscando, pues, esto: de dónde juzgaba cuando así juzgaba, había descubierto la inconmutable y verdadera eternidad de la verdad sobre ni mente mudable [...]. La potencia racional, que es la que juzga lo recibido por los sentidos del cuerpo, reconociéndose mudable en mí, se remontó hasta la inteligencia de ella misma [...] para descubrir de qué luz estaba bañada cuando, sin duda ninguna, gritaba que lo inmutable era preferible a lo mudable, y de dónde conocía lo inconmutable (lo cual si de algún modo no lo conociera, de ningún modo lo antepondría, tan segura, a lo mudable), y en el golpe de una mirada temblorosa llegó hasta aquello que es"16. Dios es el sol inteligible, que nos alumbra; el maestro interior, que responde a la razón que le pregunta. San Agustín creía coincidir con Platón en este punto, tanto que estaba convencido de que este lo recibió de las Sagradas Escrituras. El ser inmutable de Platón es el mismo que dijo en el Éxodo (3, 14): "Yo soy el que soy"17.

Para que la Verdad pueda iluminar al hombre se requiere por parte de este un doble movimiento: retornar a sí mismo y trascenderse. "No salgas fuera, retorna a ti mismo: la verdad habita en el hombre interior. Y si hallas que tu naturaleza es mudable, trasciéndete a ti mismo. Pero, al trascenderte, recuerda que trasciendes un alma razonante. Dirígete, pues, a donde se enciende la verdadera luz de la razón. Pues ¿adónde llega todo

\footnotetext{
14. ÍD., Confesiones 10, 40, 65.

15. ÍD., ib. 7, 10, 16.

16. ÍD., ib. 7, 17, 23.

17. Cf. ÍD., La ciudad de Dios 8, 11.
} 
buen razonador sino a la Verdad?"18. Relumbra aquí lo leído en los libros neoplatónicos sobre la reminiscencia: "Porque no es yendo fuera como el alma contempla la templanza y la justicia, sino que las ve por sí misma, dentro de sí misma, en la intuición de sí misma y de lo que anteriormente era, viéndolas como estatuas erigidas dentro de ella tras haberlas dejado bien limpias, pues estaban herrumbosas por el tiempo"19

Nada de esto queda ya cuando hablamos de educación. Los conocimientos se adquieren y no es nada fácil llegar a ellos. Ni innatismo ni iluminisno sino codos y transpiración. Los valores varían a lo largo del tiempo, también en los diferentes países. El niño nace en una sociedad concreta, en una cultura. Esta le va moldeando, va tejiendo en él una urdimbre y una trama inextricables. Es el llamado proceso de socialización o enculturación ${ }^{20}$. Con el tiempo, el sistema referencial del individuo puede ir cambiando, aunque en su "cueva de Altamira" (Rof Carballo) quedarán indelebles para siempre, las afirme o las rechace, las adquisiciones de sus primeros años. Por eso es tan difícil entendernos. No es fácil decidir qué es lo que hay que enseñar y con qué métodos. Hoy entendemos por educación el desarrollo de la persona en todos sus aspectos, la adquisición de saberes y comportamientos. Unos y otros se aprenden.

Formación es la acción y efecto de formar, de dar forma. Forma, etimológicamente, significa ‘molde’. Las monedas y los quesos están hechos a molde. También lo esta la Sagrada Forma. Forma es la manera en que está distribuida la materia de un cuerpo, su configuración, su disposición exterior. Formar a alguien es darle forma, ahormarle, meterle en una horma (forma), vaciarle en un molde, en determinados usos y costumbres, en las tradiciones de los mayores, por ejemplo. En una época en que se han roto los moldes, la formación queda muy lejos de su etimología, y hoy la entendemos como educación en general o como adiestramiento en detrminada materia o actividad. Formar a alguien es "darle preparación intelectual, moral o profesional"21.

18. ÍD., La verdadera religión $39,72$.

19. Plotino, Enéadas 4, 7, 10. "Dios está cerca de ti, contigo está, está dentro de ti, da consejos magníficos y rectos. Cuál Dios es cosa incierta", se lee en la Carta 41, de Séneca, y lo mismo se puede leer en otros muchos autores paganos, Virgilio entre ellos.

20. "Socialización. Integración del niño en la vida social" (María MOLINER, Diccionario de uso del español, Editorial Gredos, Madrid $1998^{2}$, s. v. socialización). La palabra no está registrada en el DRAE. "Enculturación. Proceso por el cual la persona adquiere los usos, creencias, tradiciones, etc., de la sociedad en que vive" (Diccionario de la Real Academia Española, Madrid $2001^{22}$, s. v. enculturación). La palabra no está registrada en María Moliner. 
Las palabras no son inocuas, ni son intercambiables, aunque con el tiempo pueden cambiar de significado. Hoy se habla mucho de acompañamiento, especialmente en el terreno espiritual y vocacional, y se habla, sobre todo, de aprendizaje. Este nuevo lenguaje sobre la educación está indicando una nueva visión de la misma.

\section{EL ACOMPAÑAMIENTO}

Acompañar es estar o ir con otro u otros, estar o ir en su compañía, participar en sus sentimientos. Nadie se acuerda ya de su significado etimológico: 'comer de un mismo pan', 'compartir el pan con otro u otros'22. Es una palabra muy usada hoy día hablando de la vocación. Hay muchas clases de acompañamiento: en la familia, en la escuela, en el trabajo, con los amigos, en la comunidad eclesial... El acompañamiento espiritual trata de que el acompañado llegue a vivir personalmente su relación con Dios, de que descubra en su propia vida -en su historia y en el mundo que le rodeala presencia de Cristo resucitado ${ }^{23}$. Es un tema en el que no voy a entrar. Resaltaré sólo aquellos aspectos en los que este acompañamiento coincide con la orientación que sigue actualmente la educación.

En el acompañamiento espiritual, el que tiene que hablar es el acompañado. El acompañante escucha, crea una relación fluida en la que el otro se sienta cómodo y pueda expresarse con confianza, sugiere, dice la palabra oportuna en el momento oportuno, le ayuda, le orienta, le muestra la dirección del camino, pero es el acompañado el que tiene que andarlo y hacer su propia experiencia de Dios (no la del acompañante, ni la que lea en los libros -no hay clonación posible-, aunque uno y otros le ayuden). Aquí está prohibida la repetición porque ante Dios cada uno es único (por desgracia no siempre es así entre los hombres). Ante él todos tenemos rostro y nombre propios, todos somos alguien, personas. "A las ovejas propias las llama por su nombre y las va sacando [...]. Camina delante de ellas, y las ovejas le siguen porque conocen su voz" (Jn 10,3-4). Comenta fray Luis de León: "No guarda una regla generalmente con todos y en todos los tiem-

21. Manuel SECO - Olimpia ANDRÉS - Gabino RAMOS, Diccionario del español actual, Aguilar, Madrid 1999, s. v. Forma.

22. Compañía, del lat. vg. *compania, deriv. de panis, 'pan'. Compania es un calco semántico del germánico ga-hlaiba, 'el que comparte el pan' (cf. Rafael LAPESA, Historia de la lengua española, Editorial Gredos, Madrid 1980, 117$)$.

23. Cf. Mark ROTSAERT, Accompagnement spirituel et pastorale des vocations, en Seminarium 35 (1995) 545-563. 
pos, sino en cada tiempo y en cada ocasión ordena su gobierno conforme al caso particular del que rige [...]. No mide a sus ganados por un mismo rasero, sino atiende a lo particular de cada uno que rige [...]. Llama por su nombre a cada una de sus ovejas, que es decir que conoce lo particular de cada una de ellas, y la rige y llama al bien en la forma particular que más le conviene, no a todas por una forma, sino a cada cual por la suya"24. El verdadero guía en esta historia personal de salvación es Cristo, y el acompañante tiene que ayudar al acompañado a dejarse guiar por Él. Aquí sí que se trata de una enseñanza personalizada.

El acompañamiento espiritual no debe limitarse a lo estrictamente espiritual. ¿Dónde está el espíritu en estado puro? Hay que acompañar al hombre concreto, a todo el hombre, en su trabajo y en los estudios, en sus relaciones familiares y sociales, en su fe, en sus crisis, en sus sentimientos, en sus certezas y en sus dudas, en sus cualidades y en sus defectos, en sus sueños, en sus dificultades y en sus proyectos; al hombre tal cual es, al hombre de carne y hueso, como diría Unamuno. La realidad radical, como dijo Ortega y Gasset, es la vida individual, la de cada uno, que es él y su circunstancia 25 . De ella tiene que partir toda educación que pretenda formar personas y no se resigne a transmitir sólo conocimientos. De ella hay que partir y no abandonarla nunca en el proceso de madurez cristiana y en el discernimiento vocacional. Hay que ayudar al acompañado a que descubra sus sentimientos profundos, aquello en que es único, y ayudarle a encontrar las palabras con que nombrarlos, paso necesario para que se acepte a sí mismo y aprenda a resolver sus conflictos. Pero uno y otro, acompañante y acompañado, tienen que tener en cuenta que lo más profundo de la persona es inefable, indecible, y hay que respetarlo. La alteridad es consustancial a la persona. ¿No será esta alteridad radical de lo humano un indicio de que hay una realidad más profunda que nos desborda a todos y en la que todos "vivimos, nos movemos y existimos" (Hch 17, 28)? El acompañante tiene que respetar, sobre todo, la relación del acompañado con Dios sin interferir en ella. Desde siempre se ha hablado del "sagrario" de la conciencia. Hay zonas en las que no es posible entrar sin profanarlas.

24. De los nombres de Cristo, edición de Cristóbal Cuevas, Ediciones Cátedra, Madrid 1977,224 y 233.

25. Cf. El hombre y la gente, Espasa-Calpe, Madrid 1972, 38-52; ÍD., Meditaciones del Quijote, comentario por Julián Marías, Ediciones de la Universidad de Puerto Rico, Revista de Occidente, Madrid 1957, 43-44 y 266-267. 


\section{EL APRENDIZAJE}

\subsection{Práctica y teoría}

Últimamente está ganando terreno una palabra muy usada en otros tiempos en los oficios artesanales: aprendizaje. Es un vuelco a la manera de entender la educación, a sus métodos y a sus contenidos. El aprendiz de pintor, por ejemplo, entraba en el taller de un maestro, y allí, gradualmente, mediante la práctica y las enseñanzas que este le daba, iba adquiriendo el arte de la pintura. La educación, cuando se convierte en aprendizaje ${ }^{26}$, pivota en torno al alumno, que se convierte en sujeto activo y en protagonista principal de la misma. Este ya no se limita a recibir las lecciones y, en el mejor de los casos, a empollarlas, a ser un "buen estudiante", sino que participa en la clase, escucha, practica la asignatura bajo la dirección del maestro, se inventa deberes, pregunta, se abre al saber, queda abierto a él de por vida. Practicar y reflexionar, reflexionar y practicar. Es un cambio de perspectiva.

¿De qué sirve estudiar matemáticas, física o química si no se practican, si el estudiante no se convierte en aprendiz de estas asignaturas? Pues lo mismo ocurre en las demás materias. La teoría sin la práctica no sirve de nada, y es esta la que debe preceder y acompañar a aquella ¿Para qué sirve estudiar Gramática si no se aprende a leer y a escribir? Para llenar la cabeza de borra. Antes de analizar las estructuras del lenguaje, hay que apren-

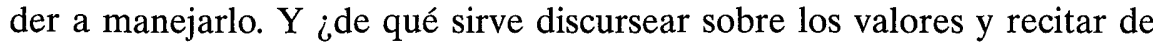
memoria los derechos humanos si no se los practica? ¿Cómo pueden saber los alumnos qué son los valores si no se los inicia en ellos? Repetirán lo que han estudiado y se quedarán sin saber lo que realmente son. ¿De qué sirve escribir una y otra vez sobre la opción por los pobres si, al fin, se termina dándoles una limosna para apaciguar la conciencia, y a lo mejor ni eso? Uno puede repetir de carrerilla la tabla de vinos, pero nunca sabrá discernirlos si no ha practicado asiduamente su degustación. Nadie puede apreciar el sabor de la libertad si no ha aprendido, en un prolongado esfuerzo personal y compartido, a ser libre. "De ahí que desde hace algún tiempo no se alcance otro método más fecundo para transmitir valores éticos que el de iniciar a niños y a adultos en los secretos de un largo proceso de degustación. Se aprende a apreciar los buenos valores degustándolos, igual que aprendemos a valorar los buenos vinos catándolos"27.

26. La fórmula semántica de aprender en Juan MATEOS., íb., 30.

27. Adela CORTINA, El catador de valores, en El Cultural 19-3-2000, 3. 
Como siempre, Ortega y Gasset se adelantó a lo que hoy se dice. El maestro, decía, debe practicar la pedagogía de la alusión, "única pedagogía delicada y fecunda. Quien quiera enseñarnos una verdad que no nos la diga: simplemente que aluda a ella con un breve gesto, gesto que inicie en el aire una ideal trayectoria, deslizándonos por la cual lleguemos nosotros mismos hasta los pies de la nueva verdad. Las verdades, una vez sabidas adquieren una costra utilitaria; no nos interesan ya como verdades sino como recetas útiles. Esa pura iluminación subitánea que caracteriza a la verdad, tiénela esta sólo en el instante de su descubrimiento. Por esto su nombre griego, alétheia-significó originariamente lo mismo que después la palabra apocalipsis-, es decir, descubrimiento, revelación, propiamente desvelación, quitar de un velo o cubridor. Quien quiera enseñarnos una verdad, que nos sitúe de modo que la descubramos nosotros"28. Quien quiera enseñarnos una verdad, que no nos la defina, que nos enseñe cómo llegar hasta ella para poderla descubrir nosotros. "Es absolutamente imposible, escribe García Morente, decir de antemano qué es filosofía. No se puede definir la filosofía antes de hacerla, como no se puede definir en general ninguna ciencia, ni ninguna disciplina, antes de entrar directamente en el trabajo de hacerla"29.

Descubrir personalmente la verdad, ir más allá de lo que dice el maestro, desvelar lo que en él está simplemente sugerido: tal es ta tarea del buen discípulo. Tal es la tarea que asignaba san Agustín a sus alumnos. A los que estaban con él en el retiro de Casiciaco les decía: "Conmigo, sobre todo mientras estéis en la época del desarrollo y la educación, tened como norma volver a discutir las afirmaciones hechas precipitadamente"30. Tenían "a disposición algunos libros"31. Además, y sobre todo, los estimulaba a que buscaran, "fuera de los libros", temas de investigación y reflexión en los que cada uno se ejercitara por su cuenta según su capacidad intelectual. “Trabajaban tanto durante el día, que no me atrevía a quitarles parte del sueño para sus estudios. Incluso les había mandado que, más allá de los libros, tratasen consigo otros asuntos, ut aliquid et praeter codices secum agerent, para que acostumbraran a su alma a vivir con ellos" y no vagar dispersa ${ }^{32}$. ¡Inventarse deberes!: he aquí la señal del buen estudiante. "El

28. José ORTEGA Y GASSET, Meditaciones del Quijote, edic. cit., 80-81 y 294-305.

29. Manuel GARCÍA MORENTE, Lecciones preliminares de filosofia, Editorial Losada, Buenos Aires $1977^{19}, 1$

30. Contra los académicos $1,3,8$.

31. ÍD., El orden 1, 2, 5. 
deber que se nos exige ha de ser tan solo un pretexto para inventar otros deberes"33. "Ya el gran físico Ostwald, en el ocaso de su vida de magisterio, decía que el único síntoma que podía poner al profesor sobre la pista de la excelencia de un estudiante novato era el que no se contentase con la labor impuesta y se crease otras a sí mismo. Absoluta verdad"34.

Todos los conocimentos se han originado así: alguien no se limitó a recibir y asimilar los conocimientos transmitidos, a ser un "buen estudiante", sino que echó en falta algo y lo inventó. Lo inventó porque lo necesitaba. "Los que crearon el saber es que sintieron no el vago afán de saber, sino el concretísimo de averiguar tal determinada cosa" 35 . No es que alguien les impusiera esta necesidad, sino que la sintieron ellos y los llevó perenteriomente a buscar, y porque buscaron, encontraron.

Por esto es un problema el estudiar, porque el estudiante no ha sentido las preguntas a que las ciencias contestan. Estas son algo que le es impuesto para obtener un título académico, no algo que él necesite vitalmente. "La solución a tan crudo y bicorne problema [...] no consiste en decretar que no se estudie sino en reformar profundamente ese hacer humano que es el estudiar y, consecuentemente, el ser del estudiante. Para esto es preciso volver del revés la enseñanza y decir: enseñar no es primaria y fundamentalmente sino enseñar la necesidad de una ciencia y no enseñar la ciencia cuya necesidad sea imposible hacer sentir al estudiante"36. ¡Hacer sentir la necesidad! Esto es lo decisivo. Lo cual no se logra con un discurso sobre su importancia el primer día de clase, sino haciendo que el alumno se vaya adentrando en ella, casi sin sentirlo, practicándola con él, de modo que se despierte su interés por ella, que sienta la necesidad que de ella tiene. Dice Karl Whitaker. "nada que valga la pena saber puede enseñarse. Tiene que ser aprendido. Tiene que ser descubierto por cada uno de nosotros"37. Cada uno tiene que hacer su propio camino, pero necesita ayuda y animación y, en los años de infancia y juventud, guías que le acompañen y orienten. Estamos deformados por una educación rutinaria y magisterial

32. ÍD., ib. 1, 3, 6; cf. José VEGA, La vocación agustiniana. El proyecto filosóficomonástico-sacerdotal de san Agustín, Estudio Agustiniano, Valladolid 1987, 123.

33. Gregorio MARAÑón, Crítica de la medicina dogmática, en Obras completas, EspasaCalpe, Madrid 1967, III, 336.

34. ÍD., Vocación y ética y otros ensayos, ib., 340.

35. José ORTEGA Y GASSET, Unas lecciones de metafísica, Ediciones de la Revista de Occidente, Madrid 1974, 17.

36. ÍD., íb., 26-27.

37. Cit. por Salustiano MATEOS GÓMARA, La autoestima: asignatura pendiente, en Educadores 37 (1995) 171. 
que no sabe suscitar el deseo de saber, que no hace sentir su necesidad. Quienes hemos tenido la suerte de tener un maestro de verdad sabemos el cambio que su presencia de luz y entusiasmo supone en la vida. Pero nunca es tarde. Mientras haya sol en las bardas, siempre es tiempo de aprender, de adquirir lo que no tenemos, pero tendríamos que tener. Porque no basta con saber lo que tenemos. Hay que saber también lo que tendríamos que tener y no tenemos, descubrir nuestras necesidades. ¡Cómo cambiarían nuestras vidas con la luz que sobre ellas arrojase este echar en falta! ¡Cómo cambiaría una comunidad si, al hacer su proyecto, junto al inventario de lo que tiene supiera hacer el de lo que no tiene, pero es preciso que tenga, el de lo que echa en falta porque lo tiene que tener y no lo tiene!. Sin este echar en falta, caemos inevitablemente en la mediocridad y la soñera.

"Todos nosotros tenemos un único maestro, Cristo; bajo él somos todos condiscípulos", dijo san Agustín ${ }^{38}$. Tenemos que generalizar el principio y convertirlo en lema de nuestra vida: en la escuela de la realidad, todos somos condiscípulos porque todos somos alumnos, aprendices de por vida, incluso en el campo que cultivemos con más asiduidad. Y nos necesitamos mutuamente. Quien crea lo contrario se condena a no ser, se está destruyendo a sí mismo.

\subsection{Razón del aprendizaje}

Somos fisiología. Hoy ya no cabe duda sobre ello. Incluso nuestras facultades más espirituales tienen un componente fisiológico. Algunos de nuestro comportamientos tienen en su raíz algún gen y lo tienen bastantes de nuestras enfermedades. Lo tienen algunas de nuestras habilidades y nuestras incapacidades. Pero somos también, con igual rotundidad, libertad, aprendizaje, cultura, narración, fábula. Y porque somos sobre todo esto último, no nos hemos conformado con vegetar, sino que hemos inventado el lenguaje, el mito, la religión, la filosofía, el arte, la ciencia, la familia, la sociedad, el derecho.... Todo lo que sabemos sobre nuestros genes y nuestra biología es fruto del aprendizaje. Fisiología y aprendizaje están inextricablemente unidos en nosotros. El genoma no existe aislado. Es siempre el genoma de alguien y este alguien vive en un entorno cósmico, social e histórico. Vivimos en un mundo de relaciones. Nuestro crecimiento 
humano, el aprender a dirigir valiosamente nuestra conducta, es un constante ir de la experiencia a la cultura y de ésta a aquélla.

Salimos del reino animal, huimos de él. Hubo en el reino animal un salto cualitativo y apareció el hombre. Pero seguimos con los posos de nuestras viejas estirpes que nos condicionan y en parte nos determinan. Somos naturaleza e historia, determinismo y libertad, azar y elección. El aprendizaje nos determina también. La sociedad con sus usos y costumbres, con sus ideas y creencias, con sus valores nos moldea aun antes de nacer. Estamos colonizados. La memoria filética y la memoria colectiva actúan, aunque no lo sepamos, en nosotros. Y actúa para bien o para mal, como limitación o como impulso, nuestra memoria personal.

A pesar de todo, podemos ser nosotros, cada uno él. Esta es nuestra ventura y nuestro riesgo. Aprendamos a serlo. Porque el hombre nace sin estar hecho. Tiene que hacerse, hacer su ser, elegir lo que va a ser y serlo. En esta tarea, nadie puede sustituir a nadie. El hombre puede hacerse inteligente, libre, justo, tolerante..., o hacerse intolerante y brutal. Hasta el cerebro lo tiene, cuando nace, sin terminar. Es la interacción con el entorno, con un entorno acogedor, la que lo irá configurando, creando las neuronas que le faltan, complementando las estructuras neuronales con que nació. En el cerebro, hay células madre, que producen nuevas neuronas en situaciones favorables. Es este de la neurogénesis uno de los grandes descubrimientos de la segunda mitad del siglo $\mathrm{XX}^{39}$. A cada uno se le dan unos datos, tiene un cuerpo y no otro, un temperamento y no otro, nace en una familia y no en otra, en un lugar y no en otro, en un tiempo y no en otro. Dentro de este contexto, cada uno tiene que escribir su propio texto, ser el novelista de sí mismo como decía Ortega. Lo escribirá, quiera o no. Pues de tener que escribirlo, mejor es escribirlo bien que mal. "De tocar las castañuelas, mejor es tocarlas bien que tocarlas mal", escribió el agustino Juan Fernández de Rojas en La crotalogía o arte de tocar las castañuelas. De tener que hacerse, mejor es hacerse bien que mal. Mejor es aprender el arte de hacerse que hacerse a la buena de Dios. Ningún otro arte es comparable a este de hacerse a sí mismo, de tomar en las manos la propia vida e ir entallando la figura que más amamos, la nuestra. Cada uno la suya. Esta es la gran tarea de la educación.

Semejante idea de la educación es un vuelco respecto a lo que habitualmente se ha hecho. La educación fue siempre, salvo en muy contados

39. José M. Rodríguez Delgado, La mente del niño. Cómo se forma y cómo hay que educarla, Aguilar, Madrid 2001. Libro que trata de la educación desde los conocimientos biológicos. 
casos, transmisión de saberes, repetición de lo ya sabido, al par que moldeamiento en los valores tradicionales impuestos por la sociedad; sumisión, en suma, al orden establecido, establecido por Dios desde la eternidad según decían. Prohibido sacar los pies de las alforjas, que "la paz de todas las cosas es la tranquilidad del orden" 40 . Lo expresó sin tapujos en el siglo pasado Bravo Murillo: "Lo que queremos no es hombres que piensen, sino bueyes que aren". Con razón se quejaba Francisco Ferrer unos años antes de ser fusilado por los sucesos de Barcelona de 1909: "No tememos decirlo: queremos hombres capaces de evolucionar incesantemente; capaces de destruir, de renovar constantemente los medios y de renovarse ellos mismos; hombres cuya independencia intelectual sea fuerza suprema, que no se sujeten jamás a nada; dispuestos siempre a aceptar lo mejor, dichosos por el triunfo de las ideas nuevas y que aspiren a vivir vidas múltiples en una sola vida. La sociedad teme tales hombres; no puede, pues, esperarse que quiera jamás una educación capaz de producirlos" 41 .

\section{LA EDUCACIÓN INTEGRAL}

Se dice, y todos estamos de acuerdo en ello, que la educación debe ser integral, facilitar el desarrollo armónico de la persona en todos sus aspec$\operatorname{tos}^{42}$. Lo difícil es ponerse de acuerdo sobre cuáles son estos y cuál la jerarquía que entre ellos hay que establecer. Todo depende de la visión que se tenga del hombre, de la clase de hombre que se quiera formar. Lo evidente es que, hoy por hoy, la educación está muy lejos de acercarse a esta meta. Lo que de hecho existe son fragmentos de educación, entre los que, como siempre, el lugar de privilegio se lo lleva la inteligencia académica, la que se mide por los tests, la que ayudará a triunfar en la vida y tener un sustancioso sueldo. Hace falta un gran debate sobre la educación. Los partidos y las iglesias de todo tipo tienen sus programas y tratan de imponerlos. Más que personas quieren adeptos, clientes. El resultado ahí está: el fracaso absoluto de la educación.

Ha habido en la humanidad grandes genios, famosos conductores de pueblos, hombres que han horadado el futuro y lo han traído; pero cuando se conoce de cerca su vida, sobreviene, sin poder evitarlo, la decepción.

40. San Agustín, La ciudad de Dios 19,13, 1.

41. Tomo las dos citas de Alfredo MATEOS PARAMIO, La polémica entre latinos y anglosajones y la educación en el fin de siglo, en Ínsula 613, 14-15.

42. Cf. Alfonso LÓPEZ QUINTÁs, Cómo lograr una formación integral, San Pablo, Madrid 1996. 
Grandes en algún aspecto, pero pequeños, pequeñísimos en otros. Raro es el que, como persona, da la talla. Ante los genios, es preciso no poner beatamente los ojos en blanco y caer en la adoración. Si hurgamos un poco en sus vidas, nos encontraremos con frecuencia con seres de pésima catadura, lo cual se presta a muy graves reflexiones sobre la educación. La psicología habla, con razón, de "idiotas sabios", personas que, a pesar de sus deficiencias en otros aspectos, poseen alguna habilidad especial, excepcionalmente desarrollada. Pueden calcular, por ejemplo, en qué día de la semana cayó una fecha cualquiera, o tocar con destreza algún instrumento musical, o pintar admirablemente bien; hacen diabluras con los números, tienen una memoria prodigiosa... ¿Son inteligentes? Así se los llama con frecuencia, aunque indebidamente. Sus habilidades son demasiado fragmentarias para merecer este nombre. Muy hábiles en tal o cuál aspecto, pero incapaces de "suscitar, controlar y dirigir las propias operaciones mentales" 43 ; incapaces de atender a las verdades y a los valores, que es en lo que consiste ser inteligentes. Por desgracia, hay más "idiotas sabios" de los que se cree. Picasso y Dalí fueron pintores extraordinarios, pero estuvieron muy lejos, y a su vida me remito, de ser inteligentes. Ser inteligente es mucho más que hacer una carrera brillante. Se puede sacar matrícula de honor en todas las asignaturas y ser un perfecto "idiota sabio”. ¿Por qué va a ser más inteligente el que entiende la teoría de la relatividad que el que sabe organizar su vida sentimental y establecer relaciones satisfactorias con los demás? Hay muchas clases de inteligencia. Es necesario corregir radicalmente la práctica de la educación. Al lado de los conocimientos tiene que haber un lugar para la educación de los sentimientos y de las motivaciones y de las relaciones sociales y de los valores humanos. Hay que aprender a discernir la jerarquía de los valores, qué acciones son más estimables, cuáles menos y cuáles son rechazables.

Educar es formar personas maduras, adultas, conscientes, libres y responsables; personas que estén orientadas en la selva que es la vida. La educación tiene que transmitir críticamente, y el educador tiene que poseer, el sistema de convicciones vigentes, "el sistema vital de las ideas de cada tiempo" 44 , de las "ideas vivas que cada tiempo posee" 45 , de las que se necesitan para vivir porque sin ellas el hombre se encuentra perdido. Ideas que pueden ser científicas o no, eso es lo de menos. En nuestra cultura

43. José Antonio MARINA, Ética para náufragos, Editorial Anagrama, Barcelona 1995, 89 y passim. Cf. ÍD., Teoría de la inteligencia creadora, Editorial Anagrama, Barceloma 19956 , 15-28 y passim. ÍD., Los idiotas sabios, en ABC Cultural 7-2-97, 61. 
occidental, hoy, la mayor parte de ellas proceden de la ciencia, pero no siempre ha sido así, ni es así en otras culturas. Estar educado es poseer la cultura que es plenamente actual, desde la que consciente o inconscientemente se vive. Hay que esforzarse por poseer las ideas de nuestro tiempo, pero no fragmentadas, pese a los posmodernos, sino estructuradas, en sistema; esforzarse por llegar a tener las claves de nuestro tiempo, los temas fundamentales de que se ocupan hoy las ciencias, sus métodos de conocimiento, la síntesis de su evolución histórica.

"Hay siempre un sistema de ideas vivas que representa el nivel superior del tiempo, un sistema plenamente actual. Este sistema es la cultura. Quien quede por debajo de él, quien viva de ideas arcaicas, se condena a una vida menos, más difícil, penosa y tosca. Es el caso del hombre o del pueblo incultos. Su existencia va en carreta, mientras a la vera pasan otros en poderosos automóviles. Tiene aquella una idea del mundo menos certera, rica y aguda que estas. Al quedar el hombre bajo el nivel vital de su tiempo -relativamente- es un infrahombre" 46.

\section{LA TERCERA CULTURA}

\subsection{Letras y ciencias}

Durante siglos y siglos no hubo separación entre ciencias y letras. En las universidades medievales, se estudiaba el trivio (gramática, retórica y dialéctica) y el cuadrivio (aritmética, música, geometría y astrología) como propedéutica para la filosofía, puesto todo al servicio de la teología o discurso sobre Dios. Era una sociedad teocéntrica y teocrática. La religión lo dominaba todo. Pero a finales del siglo $\mathrm{XV}$, comenzó a distinguirse entre letras humanas y letras divinas o ciencias sagradas (teología y Biblia). Aquellas iniciaron un lento proceso de secularización y autonomía respecto a estas. Nadie fue entonces más allá que Lorenzo Valla. Los laicos empezaron a sacudirse el yugo de los clérigos. Les ha costado Dios y ayuda, pero lo han logrado, aunque los clérigos se empeñan todavía en mantenerlos sometidos. Tiempo perdido. Voces en el desierto.

En las letras humanas, sin embargo, seguían incluyéndose todos los conocimientos de origen humano. En los textos de esos siglos, se habla

44. José ORTEgA y GASSET, Misión de la Universidad, en El libro de las misiones, Espasa-Calpe, Madrid 19597, ${ }^{73}$.

45. ÍD., ib., 102.

46. ÍD., ib., 105. 
indistintamente de "progreso científico" o "progreso literario". En 1754, hay un texto de Duclos, citado por Littré, en el que se distinguen las letras, las ciencias y las artes según el uso actual; pero la distinción no se impuso hasta mucho más tarde. En 1745, refiriéndose a las ciencias naturales, Feijoo escribe sobre el atraso literario en que estaba sumida España. Y así se siguió diciendo hasta bien entrado el siglo XIX ${ }^{47}$. Desde entonces, la separación no ha hecho más que ahondarse. Letras y ciencias se separaron y, dentro de cada campo, han ido surgiendo especialidades y especialidades hasta límites insospechados. Cada uno cultiva su parcela y lo ignora todo de las demás. Es la barbarie del especialismo. Es lo que Ortega llamaba "el terrorismo de los laboratorios". Leslie Groves, el general que dirigió el Proyecto Manhattan, con el que se produjeron las primeras bombas atómicas, impuso una norma de hierro: "Cada persona debería saber todo lo que necesitaba conocer acerca de su trabajo y nada más". Después de la guerra, esto pasó a otros campos de la investigación. Lo ilustró bien Charles Chaplin en Los tiempos modernos. Es la mejor forma de vivir en un mundo feliz de irresponsables.

\section{2. El dominio de la ciencia}

Hoy en día, en casi todas las lenguas, cultura es sinónimo de humanidades (arte, literatura, filosofía, religión... ). Si se dice de alguien que es un hombre culto, nadie piensa en un científico. Pero estos hombres cultos ignoran las más elementales nociones científicas y hasta se glorían de ello. Conocida es la salida de tono de Unamuno: " $Q$ Que inventen ellos! [...]. Ellos a la ciencia de que nos aprovecharemos; nosotros, a lo nuestro" 48 . Tuvo un predecesor ilustre en Quevedo burlándose del "cubo óptico, que llaman antojo de larga vista. [Al holandés que quería engañar a los indios, le contesta el jefe después de mirar por él]: Instrumento que halla manchas en el sol y averigua mentiras en la luna y descubre lo que el cielo esconde es instrumento revoltoso, es chisme de vidrio, y no puede ser bien quisto del cielo"49.

Vivimos, sin embargo, en un mundo dominado por la ciencia. Nuestra vida cotidiana depende cada vez más de la técnica. Más aún: ya no podemos entender el mundo ni tampoco a nosotros mismos si no poseemos

47. Cf. Joseph PÉREZ, L humanisme. Essai de définition, en AA. VV., Homenaje a Eugenio Asensio, Editorial Gredos, Madrid 1988, 358-360.

48. Del sentimiento trágico de la vida, Espasa-Calpe, Madrid19935 301. 
conocimientos científicos. Este es el gran reto para los cristianos. La teología precientífica ${ }^{50}$ se ha convertido en fábrica de ateos. Seguimos interpretando el mundo como si desde el Renacimiento acá no hubiera pasado nada, y han pasado muchas aguas bajo los puentes. Con tanto aferrarse al pasado, lo que se ha conseguido es que Dios haya desaparecido del horizonte de los hombres. "Dios ha muerto", dijo Nietzsche. Ha dejado de ser una evidencia común. No podemos usar la técnica actual y vivir, al mismo tiempo, en el contexto cultural del Nuevo Testamento con su mundo de espíritus y milagros. Ni podemos ignorar las adquisiciones firmes de las ciencias del lenguaje. ¿A quién puede interesarle hoy en día un Dios que "entre las nubes mueve / su carro ligero y reluciente" 51 y con su rayo "descuaja los cedros del Líbano" (Sal 29, 5); que da la salud y la enfermedad, la riqueza y la pobreza, la vida y la muerte; que machaca a los adversarios de su pueblo elegido "porque es eterna su misericordia" (Sal 136, 15ss.)? ¿Cree alguien esto? Pues es lo que se sigue rezando. ¿Qué madre no se desapuntará del cristianismo cuando oye que su hijo recién nacido está en pecado original? Todavía no hace mucho, había que expulsar de él al demonio antes de bautizarlo.

Los estragos de seguir con las viejas fórmulas están a la vista. Primeras comuniones que son las últimas. Actualmente, la fe se va sin dejar traumas de ninguna especie, como se va el pájaro de la jaula que quedó abierta. "La fe de aquella infancia, / rota al mismo tiempo que mis braguitas en el último / tobogán"52. Así de sencillo. A los jóvenes no les interesa la Iglesia y son las chicas las más liberales, las más desapegadas de la institución eclesial. Los estudios de Javier Elzo lo constatan una y otra vez. La familia ya no transmite la fe. La primera generación que no ha sido educada en la fe cristiana está ya presente desde hace unos años en la vida española. No es que no sepan nada de religión, es que no sienten necesidad de ella. Dios está de más para ellos. En la cultura secularizada, se vive, se trabaja, se construye la sociedad humana y se muere sin Dios. La angustia religiosa de Unamuno es hoy incomprensible. El cambio es tan profundo que Jaspers

49. La fortuna con seso y la hora de todos, en Obras completas, edición de Felicidad Buendía, Aguilar, Madrid 1958, I, 261-262. Cf. Américo CASTRO, De la Edad Conflictiva, Taurus Ediciones, Madrid 1961, 68.

50. Andrés TORRES QUEIRUGA, Fin del cristianismo premoderno, Editorial Sal Terrae, Santander 2000; ÍD., El problema de Dios en la teología de la segunda mitad del siglo XX, en Voces 18 (2001) 11-34.

51. Fray Luis de LEÓN, Poesía completa, edic. de José Manuel Blecua, Editorial Gredos, Madrid 1990, 10 (a Felipe Ruiz), vv. 41-42.

52. Almudena GUZMÁN, Usted, Ediciones Hiperión, Madrid 1980², 28. 
no dudó en compararlo con la hominización, el paso al neolítico o el descubrimiento del fuego. No es que haya habido cambios en el mundo, sino que el mundo ha cambiado, explica Ortega. A esto es a lo que llamamos crisis $^{53}$. Ya no se trata de cambiar las formas y los métodos en la transmisión de la fe, como se creía a raíz del Concilio Vaticano II. Son los mismos contenidos los que son rechazados. ¡Pavoroso!

Necesitamos plantear de nuevo los problemas desde la raíz, desde la cultura vital de nuestro tiempo. "Cultura es el sistema de ideas vivas que cada tiempo posee. Mejor, el sistema de ideas desde las cuales el tiempo vive. Porque no hay remedio ni evasión posible: el hombre vive siempre desde unas ideas determinadas, que construyen el suelo donde se apoya su existencia. Esas que llamo "ideas vivas de que se vive" son, ni más ni menos, el repertorio de nuestras efectivas convicciones sobre lo que es el mundo y son los prójimos, sobre la jerarquía de los valores que tienen las cosas y las acciones: cuáles son más estimables, cuáles son menos" 54 . En nuestro tiempo, como he dicho antes, la mayor porción del contenido de esa cultura vital viene de las llamadas ciencias, pero no siempre fue así, ni puede asegurar nadie que en el futuro seguirá siéndolo. Cuando las explicaciones teológicas que se dan sobre la fe no coinciden con la cultura vital, viene la desbandada. Son muchas las "verdades" que afirmamos los cristianos sin acabar de creérnoslas. Otra nos queda por dentro.

\section{3. Más allá de las dos culturas}

En 1959, C. P. Snow planteó en una famosa conferencia -la Rede lectu$r e$ - la existencia de dos culturas separadas por una infranqueable barrera de ignorancia y prejuicios recíprocos. Dos tipos de saber, dos sensibilidades diferentes. La "cientifica", representada entonces, sobre todo, por la física, es la modernidad, el futuro; la "literaria", representada por las humanidades, es el pasado, una vetustez sin porvenir. Snow quería reformar la Universidad, acercarla cada vez más a la ciencia y liberarla de las humanidades 55 . La Universidad ha seguido a Snow haciéndose cada vez más científica. Las sociedades no están dispuestas a invertir en letras, que

53. Cf. José ORTEGA y GASSET, En torno a Galileo. Esquema de las crisis, EspasaCalpe, Madrid 1965. Sobre ser cristiano en el mundo actual, cf. Pedro LAÍN ENTRALGO, El problema de ser cristiano, Galaxia Gurenberg / Círculo de Lectores, Barcelona 1997; Julián Marías, Problemas del cristianismo, BAC, Madrid 19822; ÍD., Sobre el cristianismo, Editorial Planeta, 1997; ÍD., La perspectiva cristiana, Alianza Editorial, Madrid 1999.

54. José ORTEgA y GASSET., Misión de la Universidad, en El libro de las misiones, edic. cit., 102, 103. 
de inmediato no son rentables. En realidad, el problema es más complejo. La discusión ya no se plantea entre ciencias y letras, sino entre tecnología y todo lo demás 56 .

El mismo Snow, en un apéndice que introdujo en una nueva edición de su conferencia publicada en 1963, introdujo la expresión "tercera cultura" aplicándola a las ciencias sociales, que, según él, no son ni humanidades ni ciencia. Desde entonces, la expresión ha sido muy usada, aunque con sentidos muy diversos. A veces se usa en la prensa en el sentido de la cultura hecha para satisfacer las necesidades de las masas, cultura superficial y frívola, ni literaria ni científica, aplebeyamiento, telebasura. Letras y ciencias han quedado relegadas a la periferia, supervivientes de otras épocas, especies en extinción. No es este el sentido que aquí nos interesa.

John Brockmann popularizó el término con el sentido de "divulgación científica" 57 . Según él, vivimos ya en la tercera cultura. Lo prueban los muchos libros de divulgación científica que se publican en el mundo. Los más conocidos son, sin duda, los de Arthur Koestler, Carl Sagan y Stephen Hawking entre los científicos, y los de ese gran fabricante de libros, Isaac Asimov, entre los no científicos. Libros muy vendidos, quizá no tan leídos y menos aún entendidos. El crítico de libros de The Times dio en la diana: "Señor Hawking, estamos totalmente de acuerdo con usted, pero no hemos entendido nada".

Esta divulgación, aun en el supuesto de que fuera asimilada, no basta para que las ciencias y las letras se integren en una nueva cultura. Con ella, seguimos viviendo en culturas separadas. Hay que ir más allá. "Muy pocos de los grandes escritores, aquellos que pueden perturbar y movilizar las capas más profundas de la mente, llegan a dirigirse a la ciencia verdadera en sus propios términos" 58 . Hay que llegar a nuevos códigos de valores y comportamientos que tengan como centro la persona, el hombre concreto, dejando a un lado prejuicios raciales, sexuales o religiosos. Es este, el hombre concreto, el que de verdad importa, pues no vivimos en el mundo platónico de las ideas, ni somos ángeles sin carne ni hueso, sino hombres con

55. Cf. C. P. SNOw, The two Cultures, University Press, Cambridge 1993, 3-4; ÍD., Las dos culturas y un segundo enfoque, Alianza Editorial, Madrid 1977.

56. Cf. Neil POSTMAN, Tecnópolis. La rendición de la cultura a la tecnología, Galaxia Gutenberg / Círculo de Lectores, Barcelona 1994, 10.

57. Cf. AA. VV., Ciencia y sociedad. La tercera cultura, Nóbel, Oviedo 2001.

58. E. O. Wilson, Sobre la naturaleza humana, Fondo de Cultura Económica, México 1980, 282. Cit. por José Manuel SÁNCHEZ RON, Más allá de las dos culturas, en Carlos NiETo Blanco (Ed.), Saber, sentir, pensar, Editorial Debate, Madrid 1997, 30. 
sus engurrios y sus alegrías, sus esperanzas y sus desilusiones, sus éxitos y sus fracasos, sus grandezas y sus locuras. La ciencia tiene que plantearse las eternas preguntas que han aquejado siempre a los hombres, las que han planteado los grandes humanistas. Tiene que dejarse penetrar por las humanidades y estas tienen que ser fecundadas por aquella. Está emergiendo una nueva visión del cosmos y del hombre, se están tocando ya las raíces genéticas de la especie humana, y esto nos obliga a plantearnos más radicalmente los temas de siempre, a ejercitar el pensamiento y a no comulgar con ruedas de molino, que pudieron ser verdad en otro tiempo, pero ya no lo son. Las interpretaciones de la realidad hasta ahora dadas, y la realidad no se nos da nunca fuera de una interpretación, ya no nos sirven. La filosofía perenne (denominación debida al teólogo católico Agustín Steuco, del siglo XVI), la sabiduría que viene desde el origen del mundo, siempre la misma, no existe. Como tampoco existe pareja teología.

¿Qué es el pensamiento? ¿Qué la libertad? ¿Cómo explicar la conciencia de nosotros mismos? ¿Y las normas éticas? ¿Cómo comenzó el universo? ¿Qué es la vida? ¿Qué hay detrás de la memoria y del aprendizaje? ¿Cómo se originan los sentimientos? ¿Qué mecanismos cerebrales llevan al hombre a pensar su continuidad más allá de la muerte? ¿Qué decir de la experiencia de Dios, "más íntimo que lo más íntimo de mí mismo y más alto que lo más alto de mí mismo" 59 ? ¿Es mero fruto de una descarga de endorfinas producidas por el sistema límbico (cerebro emocional) en determinados contextos, que los pacientes interpretan según su cultura? La interpretación no se hace después de la experiencia, sino al mismo tiempo que se tiene esta. Las dos son inseparables. ¿Cómo surgió la idea de Dios y en virtud de qué va cambiando a lo largo de la historia y en las distintas culturas? ¿A qué se llamó Dios en los orígenes y qué experiencia se expresó con esa palabra? ¿Se puede seguir hablando del alma como entidad distinta del cuerpo? Del encuentro de las Ciencias y de las Humanidades surgirá un nuevo marco de pensamiento y aparecerán nuevas disciplinas: la Neurolingüística, la Neuroliteratura, la Neuropsicología, la Neurofilosofía, la Neuroética, la Neuroteología, etc. "Necesitaremos ir más allá de las dos culturas tradicionales, instalarnos en un mundo cultural y político informado perfectamente de las posibilidades de la ciencia, de toda la ciencia, la "asocial" al igual que la "social", pero también del universo menos analítico, "huxleriano", de los seres humanos" 60 . Estamos en el umbral de un nuevo giro copernicano en nuestra idea del mundo, en las costas de una

59. San AGUSTÍN, Confesiones 3, 6, 11 . 
nueva terra incognita, y tendremos que aprender a poner nombres nuevos a las nuevas realidades.

Hace ya mucho tiempo, en 1939, Ortega y Gasset vio bien claro el objetivo de esta nueva cultura, la única que de verdad debe importarnos: "Hace mucho tiempo, dándose o no cuenta de ello, el hombre occidental no espera nada de la literatura y vuelve a sentir hambre y sed de ideas claras y distintas sobre las cosas importantes [...]. Es preciso estar alerta y salir del propio oficio: otear bien el paisaje de la vida que es siempre total. La facultad suprema para vivir no la da ningún oficio ni ninguna ciencia: es la sinopsis de todos los oficios y todas las ciencias y muchas otras cosas además. Es la integral cautela. La vida humana y todo en ella es un constante y absoluto riesgo. La media toda se va por el punto menos previsible: una cultura se vacía entera por el más imperceptible agujero"61.

\section{ALGUNOS APRENDIZAJES DE POR VIDA}

Las asignaturas van cambiando a partir de la infancia, varían sus contenidos, pero hay algunos aprendizajes que deben acompañarnos a lo largo de la vida. He aquí algunos, sólo algunos

\subsection{Aprender a convivir}

Vivir es convivir. Ser persona exige, inexorablemente, vivir con otros, convivir ${ }^{62}$. Sólo así puede desarrollarse. Que suprima cada uno lo que ha recibido de los demás. ¿A qué queda reducido? A su condición de animal. Sin los otros, todos andaríamos a cuatro patas, como los niños-lobo. O mejor, ni siquiera esto: no existiríamos. Yo necesito a los otros para ser yo. Yo soy porque los otros son. Incluso cuando uno es mayor y ha alcanzado un buen grado de madurez, cortar las relaciones con los otros es condenarse a malvivir, a ver cómo se va agostando su madurez. Tan frágil es nuestra condición humana cuando nos aislamos 63 .

Hay una virtud de la que se habla muy poco y cuya ausencia hace estragos en la sociedad: el civismo o sentido cívico64, "que, si se prefiere, podemos denominar sentido de la colectividad, del bien común o, incluso, de la solidaridad" 65 . Un sentido que no se refiere sólo a los grupos profesionales, al espíritu corporativo o "al orgullo del santo hábito" como se

60, José Manuel SÁNCHEZ RoN, $i b$, 35.

61. Meditación de la técnica, Espasa-Calpe, Madrid 1965, 13 y 31-32

62. Cf. José VEGA, La convivencia, en Estudio Agustiniano 30 (1995) 491-515. 
decía antes en las comunidades religiosas, sino que se extiende a lo que es común a todos los que forman parte de una misma sociedad civil. Basta darse un paseo por nuestras ciudades los lunes, a prima hora, para ver los estropicios que ha dejado tras de sí el vandalismo del fin de semana, o entrar en un lugar público frecuentado por muchedumbres para ver desperfectos por todas partes. Los vínculos entre las personas no son algo abstracto. Están hechos de pequeños detalles, de la atención a las cosas mínimas por humildes que sean.

Hoy nadie está dispuesto a sacrificarse por el bien común -hay derechos, pero no deberes-, y, sin embargo, los clásicos de nuestra tradición -griegos, latinos, modernos- nos enseñan de consuno a poner el bien común por encima del particular, porque de aquel depende este y no al revés. El bien de todos es también el de cada uno. Un solo texto: "La caridad antepone lo común a lo propio, no lo propio a lo común. Por consiguiente, cuanto cuidéis mejor lo común que lo propio, conoceréis que eso mismo habéis adelantado en la perfección"66. ¿Pero quién lee hoy a los clásicos?

Ahora bien: el patrimonio común no sólo consta de objetos materiales que hay que cuidar. Lo forman también las leyes, los usos, los valores y los proyectos que comparten los miembros de una misma comunidad. Es un patrimonio que no se puede malversar. Es un capital que facilita la convivencia, estimula la colaboración y ayuda a resolver los conflictos. Lo forman también el pensamiento acumulado por esa comunidad durante siglos, las obras realizadas por sus miembros. Uno y otro patrimonio, el material y el cultural, hay que conservarlo con esmero y aumentarlo. Es obligación de todos y también interés de todos. El patrimonio cultural tiene que ser conocido y continuado y, en la medida de lo posible, superado.

Vivir es convivir. Cada uno vive en una sociedad concreta, en un tiempo y en un lugar determinados, pertenece a una tradición y de ella se alimenta. Deber suyo es responder ayudando a construir esa comunidad, ayudando a mejorarla. Ayudar y ser ayudado, colaborar en reciprocidad: tal es la ley del desarrollo personal y comunitario. Somos herederos de un pasado, pero debemos ser herederos críticos; no limitarnos a transmitir, conservado en naftalina, lo recibido. Herederos, pero también creadores. 1998.

64. Victoria CAMPS - Salvador GINER, Manual de civismo, Editorial Ariel, Barcelona

65. Jacqueline de Romilly, El tesoro de los saberes olvidados, Ediciones Península, Barcelona 1999, 152.

66. San AGUSTín, Regla 5, 31. 
A quien se queja de que las cosas van mal hay que preguntarle: ¿y tú qué haces para que vayan bien?

Hay que cultivar el sentido de pertenencia a la comunidad o suscitarlo si no existe. A la comunidad en la que se desarrolla nuestro diario vivir y a las otras comunidades de las que formamos parte. Aprovecharse del procomún sin contribuir a mejorarlo es egoísmo redomado. Hay quienes creen que el mundo se acaba en la raya de su pueblo, lo cual es una deformidad; pero lo es también saltarse lo que está en nuestro derredor y enrolarse en las grandes causas de la solidaridad internacional, en utopías, que nunca llegan. Sólo a través de lo que nos es más próximo podemos integrarnos en el ancho mundo y ser nosotros mismos. Hay que estar abierto a los grandes horizontes sin olvidarse de lo que le pasa al vecino.

\subsection{Aprender a ser libre}

Los animales están genéticamente programados. Cada especie afronta los problemas de la supervivencia de una manera determinada. El individuo no tiene que pararse a pensar qué va a hacer. Lo hace y se acabó. En el hombre todo es distinto. No se le da la vida hecha, tiene que hacérsela. Cada cual la suya. "Ser libre quiere decir carecer de identidad constitutiva, no estar adscrito a un ser determinado, poder ser otro del que se era y no poder instalarse de una vez y para siempre en ningún ser determinado. Lo único que hay de ser fijo y estable en el ser libre es la constitutiva inestabilidad"67 Ante él se abren siempre varios caminos. ¿Cuál seguir? Tiene que elegir y justificar ante sí mismo su elección. Es libre por necesidad. Pero no siempre elige con acierto. No siempre elige aquello que más sentido tiene para su vida, lo más suyo, lo que debería hacer.

El hombre es libre, decimos, y es verdad; pero el niño cuando nace, no es libre. Nadie le responsabiliza de los desaguisados que comete por muy grandes que sean. El hombre adulto que pierde la cabeza no es libre. Un hombre en coma no es libre. La libertad no es una facultad que el hombre tenga y de la que pueda disponer a su capricho siempre y en todo lugar, como puede disponer de un brazo. La tiene en potencia, es verdad, pero sólo en potencia, o lo que es lo mismo: el hombre puede llegar a ser libre. ¿Lo será? La libertad no es un regalo sino una conquista nunca terminada, siempre con riesgo de perderla. No se es libre, se aprende a ser libre. Aprender a ser libre, a elegir personalmente con lucidez, sin interferencias

67. José ORTEGA Y GASSET, Historia como sistema, Espasa-Calpe, Madrid 1971, 44. 
ajenas y sin dejarse arrastrar por las oscuras corrientes que suben del propio subsuelo, es la tarea más noble de la vida. No hay forma superior de educación.

Según las encuestas, no hay valor en la cultura actual que se estime tanto como la libertad. ¿Pero qué se entiende por libertad? Con frecuencia, se identifica con autonomía, y esta se identifica con independencia, con actuar sin tener en cuenta a nadie, como si los demás no existieran. Pero el hombre es intrínsecamente social y se hace en relación con los demás en el ejercicio de su personal libertad. Ser autónomo no es volverse de espaldas a los demás y desentenderse de ellos. La autonomía no es independencia, autosuficiencia o autarquía como decían los antiguos ("El sabio se basta a sí mismo", "cada uno se santifica a solas acon Dios solo"68), sino relación lúcida y libre, solidaria y creadora con los otros. Ser autonómo es ser sujeto activo y responsable de las propias decisiones, que no buscan la sumisión de los otros sino el logro mutuo, el mutuo acrecentamiento de posibilidades. La autonomía no es independencia sino sinergia, colaboración consciente y responsable en el bien común.

Yo soy libre y hago lo que quiero, lo que me viene en gana, dicen otros. Libertad para ellos es espontaneidad. Es esta una idea hoy muy extendida, aunque a todas luces errónea. Los burros en el prado hacen lo que les viene en gana, pero no son libres. Pueden andar sueltos, libres en este sentido, pero no en el de elegir su conducta y ser responsables de ella. Siguen sus impulsos incontrolables, lo que les pide la gana. Pero esta no es la libertad de que estamos hablando. La libertad humana existe porque no todo es igual, porque no todo vale, porque hay límites, normas. Sin límites no existe la libertad. Existe el azar o la necesidad, no la libertad. La espontaneidad tiene que ser domesticada, sometida a una larga y meditada disciplina. La espontaneidad valiosa es la del bailarín que se pasa horas y horas en la barra. O la del futbolista que tiene muchas más horas de entrenamiento que de juego. Hace ya muchos siglos, Horacio recomendó a los poetas "la difícil facilidad": "Con materiales conocidos, me aplicaré a moldear mis versos, de modo que cualquiera esté seguro de que también él puede hacer lo mismo; pero si lo intenta, tendrá que sudar mucho y se fatigará en vano"69. "La difícil facilidad", que es resultado de muchas horas de estudio y práctica, de trato asiduo con los grandes creadores y de asimilación de sus técnicas. "Manejad asiduamente, día y noche, los ejemplares griegos"70.

68. Cf. José VEGA, La vocación agustiniana. El proyecto filosófico-monástico-sacerdotal de san Agustín, edic. cit., 487-490; ÍD., La convivencia según la Escuela Agustiniana Española del siglo XVI, en Estudio Agustiniano 32 (1997) 267-335 y 499-544. 
¿Dónde queda entonces la originalidad, uno de los valores más prestigiosos de la modernidad?. Al diablo con ella, que es una doncella pudorosa y recatada, a la que no hay modo de encontrar cuando se la busca. La originalidad es lo que se da por añadidura. En nuestros días, escribió Azorín: “¿Que cómo ha de ser el estilo? Pues el estilo... Mirad la blancura de esa nieve de las montañas, tan suave, tan nítida; mirad la transparencia del agua de este regato de la montaña, tan límpida, tan diáfana. El estilo es eso; el estilo no es nada. El estilo es escribir de tal modo que quien lea piense: esto no es nada. Que piense: esto lo hago yo. Y que, sin embargo, no pueda hacer eso tan sencillo -quien así lo crea-: y que eso que no es nada, sea lo más difícil, lo más trabajoso, lo más complicado"71. Esta es la espontaneidad valiosa. Antes que Horacio, Esquilo había dicho: "la sabiduría por el sufrimiento"72. Y un adagio latino dice: per aspera ad astra, "por las dificultades hasta los astros". "Por estas asperezas se camina / de la inmortalidad al alto asiento, / do nunca arriba quien de aquí declina"73.

La conclusión es clara. Paradójicamente, se aprende a ser libre obedeciendo, ateniéndose a una disciplina. Los ejemplos podrían multiplicarse. Veamos qué pasa en el niño, cómo se va haciendo libre quien todavía no lo es. El niño tiene que aprender a controlar sus movimientos espontáneos empezando por sus necesidades fisiológicas. Controlándose, cumpliendo las indicaciones de la madre o de sus cuidadores, es decir, obedeciendo, va creando comportamientos voluntarios, va adquiriendo esa destreza que llamamos voluntad. Obedecer significa precisamente escuchar, atender a lo oído, ob-audire, obedire, escuchar a alguien, seguir sus consejos. El niño va progresando y llega un momento en el que es él el que comienza a darse órdenes y a obedecerlas. Tras la heteronomía, comienza a ser autónomo, comienza a ser persona, libre. Hasta entonces estaba en camino de serlo.

Kant lo expresó admirablemente bien: "la disciplina es lo que consigue transformar la animalidad en humanidad"74. Desgraciadamente, según él, y en esto erró, no hay más que disciplina. Toda manifestación de afectividad está ausente de su sistema y lo ha estado durante siglos de la mayoría de los sistemas filosóficos. De ningún otro tema se ha escrito y se sigue escribiendo tanto como del amor, pero se ha teorizado poco sobre él, cuando

69. Arte poética, vv. $240-242$.

70. ÍD., ib., vv. 268-269.

71. Un pueblecito. Riofrio de Avila, Espasa-Calpe, Madrid $1957^{2}, 41-42$.

72. Agamenón, v. 178.

73. GARCIlaso DE LA VEgA, Poesías castellanas completas, edic. de Elías Rivers, Editorial Castalia, Madrid 1972, Elegía I, vv. 202-204, 
debiera ser el tema fundamental y el centro de todo plan de estudios. "El tema del amor es más que una asignatura pendiente, es una nueva estructura que debiera informar y afectar a todo el aprendizaje"75. El hombre necesita, constitutivamente, ser amado y amar. La revelación judeo-cristiana nos dice que el hombre es "imagen de Dios" (Gn 1.27), cuya realidad "es amor" $(1 \mathrm{Jn} 4,8)$. El hombre, por consiguiente, es amor antes que cualquier otra cosa. Tendrá que cultivar la inteligencia, y es lo que se hace en los cursos académicos, pero más el amor, y esto se tiene completamente olvidado. Hablo de amor, no de eso que llaman neciamente "hacer el amor". Es este un tema que hay que estudiar desde todas las laderas que confluyen en él, desde las distintas ciencias en él implicadas. Con consideraciones piadosas, que es lo que han hecho los espirituales durante siglos y siguen haciéndolo, no se va a ninguna parte.

Un proceso similar de cumplimiento de ciertas normas le permite al niño ir interiorizando el lenguaje y tomar con él posesión del mundo, iqué maravilla!; ir creando su intimidad el que todavía no la tiene, construyéndose como sujeto el que carece de toda subjetividad ${ }^{76}$. Disciplina, sin duda, pero al servicio de la persona. Disciplina que amplíe las posibilidades de actuar libremente, que haga al hombre capaz de hacer algo libremente en beneficio del procomún.

La disciplina es necesaria y es necesaria la obediencia para hacerse libres, personas. Es verdad que la obediencia y la disciplina pueden matar la gallina de los huevos de oro, destruir la persona y poner en su lugar la hipocresía, el engaño y la máscara. ¿Qué hacer? Este es el problema más grave de la educación en nuestros días. Antaño, la disciplina pecó por carta de más y el fracaso fue estrepitoso. En nuestros días, peca por carta de menos y no es menos estrepitoso el fracaso. Infantilismo ayer, pseudo-vida; revueltas estudiantiles hoy, la rebelión de los yogurines. El problema es tan grave, que en varios países la policía está ya en las aulas y en otros se ha hablado de enviar a ellas el ejército. Son muchos los estudiantes que han sufrido algúna agresión de sus compañeros y el porcentaje va creciendo según avanzan en edad. Todo indica que la violencia seguirá aumentando. En abril de 1998, ante la ola de atracos, robos, intimidaciones y abusos sexuales, entró en vigor en la Comunidad Autónoma de Madrid, en una veintena de colegios, el plan de seguridad escolar contra la violencia,

74. Cit. por José Antonio MARINA, Paradojas de la obediencia, en ABC Cultural 31-5$96,61$.

75. Manuel Cabada, La vigencia del amor, San Pablo, Madrid 1999, 23-24.

76. Cf. José Antonio MARINA, Teoría de la inteligencia creadora, edic. cit., 70-75. 
extensible a todos ellos. En cada centro se creó la figura del Coordinador de la Tolerancia. Su función es mantener informada a la policía de los brotes de violencia, tanto dentro del centro como en su entorno. A petición suya, pueden actuar dentro del colegio las Fuerzas de Seguridad.

"El problema más serio que tiene planteada la enseñanza no es el de los contenidos a enseñar, ni el de las técnicas pedagógicas, sino el de saber lo que se debe exigir y cómo se debe exigir"77, "el de definir las normas de convivencia en los centros. Asunto para el que no cuenta, en absoluto, con los padres. Hay muchos pedagogos a la violeta que se avergüenzan de hablar de disciplina, y piensan que la libertad se educa no exigiendo nada. Se olvidan de que la libertad personal no es un bien innato, sino construido, que necesita un aprendizaje duro. Es como aprender a escribir. Nadie tiene un estilo creador y libre sin conocer las limitaciones de la sintaxis"78.

Aprender a ser libre no es aprender a serlo en esta o aquella libertad que le afecte más directamente a uno, sino aprender a serlo en el sistema de libertades (religiosa, de pensamiento, de expresión, de asociación, de reunión...), porque herida una, todas quedan malheridas. Aprender a ser libre es aprender a vivir la vida como libertad. Aprendamos a respetar la libertad de los demás, a gozarnos en las diferencias.

Se aprende a ser libre, pero nunca se acaba de aprender. Es esta, como todo lo humano, una tarea de por vida. Son muchas las llamadas externas e internas que nos solicitan y coartan y enturbian nuestra elección. Al hombre le gusta someterse, formar manada, seguir a un pastor, cumplir sus consignas, echarse fuera la responsabilidad. De ahí el éxito de las sectas y de todos los grupos políticos y religiosos que anulan la libertad. Ser libre no es algo natural, ni un don caído del cielo. Es algo ganado con el propio esfuerzo, con un esfuerzo sostenido a lo largo de la vida. Quien lo consigue está siempre en un tris de perderlo. Nadie le asegura a quien hoy es libre que mañana lo será. La historia nos enseña que todo es quebradizo, fugaz. Hay que estar muy atentos para que lo conseguido no desaparezca. Al menor descuido, se desmorona.

Aprendamos a ser libres, libres de los demás, de las opiniones vigentes, de lo que está de moda; no por capricho, ni porque nos da la gana, sino porque nos hemos hecho juicio propio y somos responsables de nuestra decisión. Libres de los demás. No seamos esclavos de ellos, pero con ellos, en solidaridad con ellos. Aprendamos, sobre todo, a liberarnos de nosotros mismos; de nuestro pasado si nos aprisiona; de nuestros miedos, de los

77. ÍD., Paradojas de la obedienca, en ABC Cultural , íb.

78. ÍD., ¿Quién le pone el cascabel al gato?, en $A B C$ Cultural, 9-2-96, 61. 
oscuros impulsos que suben del océano oculto que ruge en nuestro interior "Y en la cripta sentí sonar cadenas, / y rebullir de fieras enjauladas"79. "En la formidable cruzada de liberación del hombre que es la misión del intelecto ha llegado un momento en que necesita este liberarse de su más íntima esclavitud, esto es, de sí mismo"80. "Líbreme Dios de mí", rezaba Lope de Vega.

\subsection{Aprender a exigirse}

Hay otra disciplina mucho más importante que esta externa de que venimos hablando, con serlo esta mucho. Es la disciplina que cada uno se impone a sí mismo, que es, a la vez, condición para que la otra dé su pleno rendimiento. Es este un valor que hoy no se cotiza en el mercado. Lo que hoy manda es la vulgaridad, el qué más da, la chabacanería, la obra mal hecha, la huida del esfuerzo. ¿Para qué esforzarse en hacer bien una cosa si vale lo mismo hecha mal? Diríase que las palabras exigencia, calidad, esmero, obra bien hecha son arcaísmos, un atentado a la libertad, como si esta fuera improvisación y chapuza. "Me pregunto si la sociedad actual ha abolido el ejercicio de la exigencia, si está dispuesta a pasar por todo [...]. Lo que esto revela es más grave que el cine y la televisión"81, donde toda vulgaridad tiene su asiento. Sin esfuerzo por superarse no hay alegría profunda, ni felicidad, ni autoestima que valga la pena.

Sacerdotes que celebran con desgana, que comienzan santiguándose a la diabla, que dicen rutinariamente las oraciones, que leen sin que nadie los entienda, que ignoran las reglas más elementales de pronunciación, que predican... Pero ¿es que a lo que hacen se le puede llamar predicar? ¿Es predicar decir cuatro vulgaridades para salir del paso? ¿Es predicar hablar en lenguaje que para ser entendido exige un intérprete? ¿Es predicar aburrir a los oyentes y mandarlos a casa tan a oscuras como vinieron? Profesores que repiten año tras año la misma cantilena, tan sosa, tan rayada. Estudiantes que no estudian, que no leen, que machacan la ortografía porque qué más da, a qué perder tiempo en esas minucias, y profesores cómplices de tales tropelías. Artículos y libros mal presentados y peor escritos, sin claridad y sin rigor, porque a sus a autores les da lo mismo la verdad que la mentira, el bien que el mal, la belleza que la fealdad. Lo importante para

79. Antonio MACHADO, Y era el demonio de mi sueño, el ángel..., en Galerías, en Poesía y prosa, edic. de Oreste Macrí, Espasa-Calpe, Madrid 1989, II, LXIII, 474.

80. José ORTEGA Y GASSET, Historia como sistema, edic. cit., 36.

81. Julián MARÍAS, La exigencia, en Blanco y Negro 26-8-90, 10. 
ellos es figurar, engrosar el currículum, aparecer en algún mamotreto bibliográfico para satisfacción de la propia vanidad.

¿Tanto cuesta hacer bien las cosas, hacerlas con calidad? Porque no se trata de hacer cosas extraordinarias, sobrehumanas, sino de hacer bien lo que se tiene que hacer. Nada más. Pensemos en las cosas que a diario tenemos que hacer. ¡Cómo subiría el nivel de nuestra vida si nos esmerásemos en hacerlas bien! Y como somos relación, vasos comunicantes, el nivel de cada uno se vería aumentado por el de los demás. ¡Cómo mejoraría la convivencia a poco que cada uno se esforzase por hacerla más humana y cordial, por potenciar, sin mezquindad, la realidad de los demás! Hoy se habla mucho de mejorar la calidad de vida, pero lo curioso es que se habla de la vida material y se deja fuera lo más importante, las relaciones humanas, lo personal.

Aprendamos a exigirnos, enseñemos a los alumnos a que se exijan . "A las minorías selectas no las elige nadie. Por la sencilla razón de que la pertenencia a ellas no es un premio o una sinecura que se concede a un individuo, sino todo lo contrario, implica tan solo una carga mayor y más graves compromisos. El selecto se selecciona a sí mismo al exigirse más que a los demás. Significa, pues, un privilegio de dolor y esfuerzo. Selecto es quien aspira a una altitud mayor de exigencias y perfecciones. Es un hombre para quien la vida es entrenamiento, ascetismo, para mantenerse en forma" 82 . "Por clasicismo entiendo ahora una sola cosa: férrea disciplina interior. Todas las labores valiosas que se han cumplido en la historia nacieron de esa disciplina dura, vibrante, que no consiente el menor abandono o flojera, la disciplina que reina en las plazas sitiadas. Una juventud que aspire a ser no consecuencia, repercusión, eco del pretérito en decadencia, sino, al contrario, iniciación de un proceso ascensional y constructor -el proceso en que se crea esa enorme cosa que es un gran pueblo- tiene que sentirse sitiada por el vulgo inerte. [...] Las minorías selectas son selectas -entiéndase bien- ante todo y sobre todo porque se exigen mucho a sí mismas. El hombre que se impone a sí propio una disciplina más dura y unas exigencias mayores que las habituales en el contorno, se selecciona a sí mismo, se sitúa aparte y fuera de la gran masa indisciplinada donde los individuos viven sin tensión ni rigor, cómodamente apoyados los unos en los otros y todos a la deriva, vil botín de las resacas [...]. Nada se puede esperar de hombres que no sienten el orgullo de poseer más duras obligaciones que los demás. La nobleza en el hombre, como en su hermano mayor el animal, es, ante todo, un pri-

82. José ORTEGA y GASSET, Apuntes sobre el pensamiento, Edicions de la Revista de Occidente, Madrid 1975, 65. 
vilegio de obligaciones. El caballo de raza lo es, ante todo, porque tiene obligación de correr más que el vulgar o resistir más largamente" 83

Hacer bien lo que tenemos que hacer, aunque no sea conocido, valorado ni comentado. Son estos trabajadores de la obra bien hecha los que realmente son luz y sal de la tierra. Hombres de vida exacta, diáfana, sin alardes de ejemplaridad, ahíncados en su tarea, cordialmente atentos al prójimo, luminosos sin pretenderlo, humanísimos. Estos son los héroes que necesitamos con urgencia en nuestros días, hombres entregados silenciosamente a su vocación. De ellos se puede decir lo que del inolvidable maestro Rafael Lapesa escribió Jorge Guillén:

Nada más peregrino

Que una conducta simplemente justa.

Y no según la gran justicia abstracta,

$\mathrm{O}$ en actitud preliminar de puro.

Una conducta justa por justeza

Por precisión, por limpidez, iqué rara!

Rara entre vozarrones de energúmenos

Este varón cordial

Se ahínca en su tarea

Con esfuerzo sin gesto, sin alarde ¿Hoy? Manos a la obra.

Atención a papeles

Sin cesar se combina

Con la atención al prójimo.

¿Aprendiz, ya maestro?

Manos, pues, a una ayuda.

Luz desde el alma es siempre generosa.

Ese vivir sereno se mantiene

Sobre alturas con aire

Ya libre claridad bien respirada,

Cima del intelecto,

Atmósfera de sierra.

Una tensión -sin pausa-

Tenderá a su difícil equilibrio,

Punto precario que se restablece

83. ÍD., El deber de la nueva generación argentina, en Meditación del pueblo joven, Espasa-Calpe, Madrid 1964, 31. 
Con incesante fuerza de conquista,

Entre riesgos sosiego,

A cada paso en crisis.

Baraúnda de siglos

Aún supervivientes

Rodea a este varón

Sin quebrar su silencio laborioso,

Estímulo de un aula.

Y con su firme temple de sonrisa,

-"hombre esencial" dijeron los antiguos-

Estudiando palabras y poemas

Es el docto en su quid:

Ninguno más humano.

Con linterna a lo Diógenes

Buscad sus pares, pocos 84 .

\subsection{Aprender a ser uno mismo}

Gerardo Diego soñaba con tener "un discípulo, / un verdadero discípulo, / distinto de mí y de todos; él mismo"85. Ser ella misma: esta es la exigencia fundamental de la persona, su primer y único mandamiento, un mandamiento exigido por el hecho mismo de ser persona. Ser uno mismo es seguir la propia vocación, elegirse a sí mismo, hacerse a sí mismo durante toda la vida, ser fiel a la condición humana, hacer aquello a que íntimamente se siente uno llamado, vocado ${ }^{86}$. En el origen de toda vocación está el amor, amor a aquello a que la vocación lleva. Ser uno mismo, seguir su vocación, exige entregarse en cuerpo y alma a serlo, no ahorrar esfuerzo alguno para llevar a cabo aquello que la vocación exige, aceptar los riesgos que ello lleve consigo, también el de perder la propia vida, que será un modo de salvarla (Mt 16, 25). La vida, toda vida, es misión. No es que el hombre tenga una misión, sino que el hombre es misión. Son estas ideas claramente cristianas, evangélicas, que en Jesucristo encontraron su reali-

84. Jorge GuILlÉN, Rafael Lapesa, en Aire nuestro. IV. Y otros poemas, Barral Editores, Barcelona 1979, 332-333. Para el concepto de heroísmo aquí considerado, introducido por Juan Ramón Jiménez, cf. Dámaso ALONSO, Héroes de nuestros días: Marañón, Pidal y Lapesa, en Obras completas, Editorial Gredos, Madrid 1975, IV, 990-995; ÍD., Rafael Lapesa en la Academia, íb., 283-295.

85. Brindis, en Versos humanos, en Obras completas, 1. Poesía, Aguilar, Madrid 1989, 297.

86. Cf. Pedro LAÍn ENTRAlgo, Esperanza en tiempo de crisis, Galaxia Gutenberg / Círculo de Lectores, Barcelona 1993, 253-254. 
zación plena, hoy felizmente difundidas en otros ámbitos. Ideas consustanciales con el cristianismo, pero que no siempre se han practidado en él. Durante siglos, por ejemplo, se enseñó que el religioso tenía que estar a disposición del superior como un cadáver, perinde ac cadaver como dijo san Ignacio de Loyola. La rectificación es aquí tan profunda, que aún estamos lejos de haber tocado fondo.

Característica de la persona es su unicidad. Cada persona es única, irreductible a cualquier otra, irrepetible, inintercambiable. Si, contra toda ética, se obtuvieran seres humanos por clonación, serían copia genética de un individuo, su réplica biológica; pero distintos, únicos, como personas. Porque tendrían distintas sensaciones, distintos gustos, distintas relaciones, acciones distintas, distintos recuerdos, imaginaciones distintas, distintos proyectos..., distinto aprendizaje en suma. De hecho, los gemelos monocigóticos tienen el mismo código genético, pero son diferentes. Iguales en lo recibido, en la naturaleza, pero distintos en lo que hacen. La influencia social y el ambiente los diferencia. Incluso su sistema inmunitario es distinto. $\mathrm{Y}$ es que no solo somos genética sino también aprendizaje. Tales gemelos no son la misma persona repetida sino dos. Cada una de ellas es una y única, irrepetible, irreductible a la otra. La persona no está hecha y tiene que hacerse, hacerse ella a sí misma, no que la hagan otros, elegirse a sí misma libremente con conocimiento de causa, elegir quién va a ser y cuál va a ser su profesión. Tiene derecho a ello. Esta es la razón última de la educación, y, si no es así, si la educación no la ayuda a ser ella misma, a discernir su propia vocación y la profesión y estado en que mejor podrá realizarla, la educación es un mero nombre. Cada uno tiene derecho a hacerse su propio camino, a tener su propia voz. "A distinguir me paro las voces de los ecos, / y escucho solamente, entre las voces, una"87.

Cada uno quiere y exige ser él mismo, poder serlo, participar en la comunidad de la que forma parte, que se cuente con él, que se le reconozca como persona. Quiere tener sus propias convicciones, aunque sean provisionales; buscarlas él, poder equivocarse y poder rectificar. Ser uno mismo: este es el valor hoy en auge. Este es uno de los signos de los tiempos. Pero quien exige ser él mismo debe saber que adquiere un deber: dejar que los demás también lo sean, comprometerse a que lo sean.

Ser uno mismo es ser con los otros. El egoísta, el narcisista, el individualista, el elitista, el que se aprovecha de los demás no solo los daña a ellos sino también a sí mismo. Se condena a no desarrollarse como persona, a destruir su propio ser. Quizá obtenga muchos beneficios, pero se 
queda sin el principal porque se pierde a si mismo. "¿De qué le sirve a uno, pregunta el Evangelio, ganar el mundo entero si malogra su vida" (Mt 16, 26), si se pierde a sí mismo?

\subsection{Aprender a ser solidario}

Aprender a ser libre es respetar la libertad de los otros, promoverla como requisito para nuestra libertad. Somos iguales ante la ley, pero diferentes como personas. Cada cual tiene su alma en su almario y es y siente y piensa y se relaciona y se expresa de manera diferente; y la tienen los diversos grupos humanos con su cultura y su religión. Intentar homogeneizar a los demás, coartar su libertad, aplastar las diferencias es un crimen de lesa humanidad. En la diferencia reside la dignidad humana, dice Shakespeare. "Sólo todos los hombres viven lo humano", añade Goethe. La libertad que no es solidaria de la libertad de los demás deja de serlo y se convierte en máscara de sí misma.

El que ha aprendido a ser libre cuenta siempre con el otro y su libertad, y se empeña en que lo sea. Porque todos participamos "en la misma empresa de personalización individual. Que no puede ser efectivamente del hombre si no es de todos. La empresa de ser hombre-¿no es verdad, amigo Laín?- la esboza y prosigue cada uno con los demás. Ninguno puede lograrla con alguna plenitud si no se convierte en límite y horizonte para los demás. Límite, porque yo soy yo y tú eres tú, incanjeables, propios, libres; porque mi libertad o la tuya, o las dos, o todas, dejan de serlo, si no se respetan mutuamente, cada una limitada por las otras, sin que ninguna invada, estreche o aniquile a las demás. Horizonte, porque cada uno, desde su personal libertad, abre o cierra posibilidades al otro y sólo cuando le hace más libre, creciendo él mismo en libertad, inaugura una mayor plenitud personal en el hombre. La individualización personal sólo es perfectiva cuando es un proceso de liberación. Sólo se cumple perfectamente en la libertad solidaria. No soy yo ni eres tú el que se individualiza personalmente. Eres tú y soy yo con los otros"88. Aprendamos a ser libres respetando la libertad de los otros, ayudándolos a serlo, gozándonos en que lo sean.

\subsection{Aprender a aprender o la educación permanente}

\subsubsection{Razón de la educación permanente}

88. Mariano YELA, El libro y la formación de la individualidad, en Fernando LÁZARO CARRETER (Coord.), La cultura del libro, Fundación Germán Sánchez Ruipérez, Madrid 1983, 109-110. 
Estamos en la época de la educación permanente, en la sociedad del aprendizaje continuo, del reciclaje ininterrumpido. "Quien lo entienda, saldrá adelante. Quien no lo entienda , se conectará a la red y esperará órdenes"'89.

Y esto no por capricho ni por moda, ni siquiera por los cambios tan profundos que se están realizando y que a todos nos zarandean, sino, ante todo y sobre todo, por la comprensión que actualmente tenemos del hombre, de nuestra condición de personas. Y es que, como he dicho repetidas veces a lo largo de este estudio, no estamos hechos, sino que nos hacemos, nos estamos haciendo. El hombre no es una realidad dada, hecha de una vez para siempre, que va pasando por una serie de acontecimientos externos a lo largo de su vida, sino que esos acontecimientos, los que él hace y los que le pasan, le van constituyendo, van haciendo lo que él es, su vida. La vida de cada uno: ese es su ser.

El hombre se encuentra viviendo, y al vivir explora, ensaya, hace, deshace, da, recibe, emprende, se está quieto, arriesga, se pone a salvo, acierta, se equivoca, rectifica, vuelve a empezar... Todo esto le va constituyendo, le va haciendo, va creando su ser; un ser siempre abierto, futurizo, proyectivo porque es libre. Y así hasta la muerte. Esta es la razón fundamental de la educación permanente. Aquí radica la necesidad que tenemos de aprender a aprender para estar en todo momento orientados sobre lo que vamos a hacer, para hacernos bien, mejores, conforme al modelo de hombre que juzgamos más acertado, más humano.

La historia no nos es algo extrínseco, un cauce por el que va discurriendo nuestra vida y la vida de la humanidad. Así se creyó durante siglos. Fue Dilthey quien nos sacó de ese sueño secular. La historia somos nosotros. Por eso, para saber quién es alguien necesitamos que nos cuenten su historia, y su historia nos tienen que contar para saber qué es tal sociedad, y es la historia de la humanidad el único camino que tenemos para averiguar quién es el hombre. Goethe decía con razón, y ya lo he citado: "solo todos los hombres viven lo humano", desde el encanallamiento más salvaje hasta las sublimidades del amor puro, gratuito e incondicional. ¿Qué está pasando en la actualidad? Los cambios se producen vertiginosamente. No nos hemos repuesto del último y ya nos anuncian otro. Todo va de prisa. Como en la primavera de Juan Ramón Jiménez, "es la fiesta del que corre y del que vuela"90. Nos exponemos a perder la libertad, a quedarnos a merced de lo que nos digan los gurús de la tribu, a ser piezas de robot. O

89. José Antonio MARINA, jTodos a la escuela!, en ABC Cultural 22-3-96, 61. 
aprendemos con celeridad o nos tragará la vorágine. Ya lo dice el refrán: "camarón que se duerme, se lo lleva la corriente".

Esta es nuestra situación al doblar el cabo de las tormentas del segundo milenio: vernos todos convertidos en alumnos, en aprendices por necesidad. Pero, como siempre, esta necesidad tiene que sentirla cada uno, tiene que brotar de su interior y salir hacia afuera, llevarle a satisfacerla. Quien no eche en falta el saber, ¿cómo lo irá a buscar? ¿Quién se molestará en llenar de agua la cisterna que no ve vacía? "Nadie, por excelente que sea su voluntad, puede darnos hechas nuestras convicciones. Tenemos que convencernos a nosotros mismos" 91 .

\subsubsection{Educación y vida}

Al vivir, cada uno va aprendiendo mucho o poco. Lo primero depende de la intensidad con que viva, aspecto este que casi nunca suele considerarse. La vida es una escuela irreemplazable. Nada más triste e ignorante que El príncipe que todo lo aprendió en los libros, como se titula una obra de Jacinto Benavente. Peor aún es el caso de los que ni siquiera frecuentan los libros, de los que viven en la inopia como ha sucedido con frecuencia en las Órdenes religiosas, empezando por los Padres del Yermo ${ }^{92}$. Antiguamente, se admitía en los monasterios, cerrados al mundo, a niños de muy corta edad, mucho antes de que se despertara en ellos el sexo, esperando tontamente que nunca se les despertaría; pero lo que no se les despertaba era la inteligencia, que solo por el frotamiento con otras inteligencias se va haciendo. Tema este de los niños en los monasterios que está pidiendo una buena monografía. Las historias conventuales cuentan con entusiasmo la inocencia de algunas almas candorosas que en ellos vivieron, confundiendo el candor con la estupidez, que tal es el fruto del aislamiento.

Pero el torrente de la vida necesita ser encauzado y clarificado por la cultura, que debe ser solo "la vuelta táctica que hemos de tomar para convertirnos a lo inmediato" 93 . Con frecuencia, la vida ha ido en una dirección y la escuela en otra, si es que esta no se ha empeñado en sofocar aquella. Ya Séneca se quejaba de que "no aprendemos para la vida sino para la escuela"94. Dejémonos ya de abstracciones y de abstracciones deducidas de otras abstracciones sin hacer pie nunca en lo real. Necesitamos la cultu-

90. Juan Ramón Jiménez, La cojita, en Historias, en Antolojía poética, Editorial Losada, Buenos Aires $1958^{2}, 140$.

91. José ORTEGA Y GASSET, Unas lecciones de metafísica, ,edic. cit., 145.

92. Cf. Ramón TEJA, El demonio de la homosexualidad en el monacato egipcio, en Codex Aquilarensis 11 (1994) 19-31, en especial p. 27. 
ra, pero una cultura que esté al servicio de la vida. Necesitamos permanentemente la educación, pero una educación que nos ayude a vivir, que aligere nuestra vida, que nos salve del naufragio, que nos sirva de salvavidas como dice Ortega.

\subsubsection{Buscadores de la verdad}

La verdad será inmutable, eterna, absoluta, objetiva, una para todos. Pero nosotros somos mudables, temporales, relativos, multitud innumerable hoy y ayer y mañana. Nadie puede pretender poseer $l a$ verdad, de modo que por definición todos los demás estarían en el error. Poseemos verdades parciales y provisionales, esquirlas, pizcas de verdad, interpretaciones de la realidad, que se queda siempre, diosa de los mil rostros, más allá de ellas. Necesitamos estar despiertos, bien abiertos los ojos. Nuestra actitud debe ser la de buscadores de la verdad, no la de creernos poseedores de ella. No es cierto que la verdad habite en el hombre interior. Ahí no hay ninguna verdad. Si me recluyo en mí mismo, yo no puedo encontrarme ni a mí mismo, mucho menos a Dios, que "es amor" (1Jn 4, 8). La verdad se hace, la hacemos en conexión con el entorno, sobre todo con los otros, y ahí, en mi relación con los otros, me encuentro y me conozco a mí mismo, y en ese "en", en esa relación con los otros, está Dios, como fundamento y amor, que nos llama a amar95. "El Espíritu de la verdad os irá guiando en la verdad toda, porque no hablará por su cuenta, sino que os comunicará cada cosa que le digan y os interpretará lo que vaya viniendo" (Jn 16, 13).

Hasta los defensores del innatismo o del iluminismo sostienen que la verdad no se acaba de encontrar nunca, que nos desborda y es inabarcable en una simple mirada. "Todavía voy en pos de Jesucristo, aún progreso, aún estoy en camino, todavía estoy en ruta, aún estoy en tensión, todavía no he llegado. Por lo tanto, si también tú caminas, si estás en tensión, si piensas en lo que ha de venir, olvida el pasado; no fijes en él tu mirada, no te quedes anclado en él. Somos y no somos perfectos; perfectos viandantes, que no perfectos poseedores ni moradores. Quien piensa ser algo, no siendo nada, se engaña; y quien se figura haber terminado de conocer algo, aún no ha empezado a conocer como es debido (1 Cor 8,2$)$. No nos quedemos en donde hemos llegado, sino caminemos a partir de ahí. Caminad, avanzad, hermanos míos, no caminéis perezosamente [...]. Nunca te complazcas

93. José ORTEGA Y GASSET, Meditaciones del Quijote, edic. cit., 41 y 255.

94. Cartas 106, 12.

95. José VEGA, La comunicación, en Estudio Agustiniano 34 (1999) 124-126 y 140-142. 
en lo que eres si quieres llegar a lo que todavía no eres, porque en el momento en que te complazcas, ahí te estancarás. Como digas es suficiente, perecerás. Añade siempre algo, camina siempre, progresa sin desfallecer [...]. El que no avanza está parado"96. "Aquí hay que buscar siempre. Ni por asomo se os ocurra que hay que dejar de buscar"97. Quienes de verdad aman la verdad desconfiarán siempre de haberla alcanzado. Quien cree haber llegado al final, en realidad no ha empezado.

La realidad no se nos da fuera de las interpretaciones, pero es distinta de las interpretaciones que de ella se hacen. Por eso caben tantas interpretaciones de ella. Parejamente, la realidad cristiana es una, pero caben de ella distintas interpretaciones, distintas formas de conceptualizarla y expresarla, distintos sistemas de interpretación. La realidad cambia. A nueva realidad, nuevas preguntas, y a nuevas preguntas, nuevas soluciones. El Evangelio no nos da soluciones, pero nos dice en qué dirección debemos buscarlas: en el respeto a la dignidad de la persona y para bien suyo (Mc 2, 27-28). A estas alturas de la historia no caben dudas sobre el particular. Necesitamos aprender las interpretaciones que hoy se están haciendo de nuestra realidad cristiana, las que hizo el Concilio Vaticano II y las que posteriormente están haciendo cristianos responsables de su fe.

\subsubsection{Educación permanente integral}

Necesitamos aprender, estar aprendiendo siempre, y el aprendizaje ha de ser integral. Sería un error gravísimo prolongar la situación que ha padecido y sigue padeciendo la educación: dedicación absoluta al saber intelectual. Conocimientos, muchos conocimientos, acumulación de datos, erudición, preparación de los caballos para la carrera de las oposiciones con la esperanza de un buen pesebre para los ganadores. Resultado: mutilación de la persona, que no sabe quién es ni sabe convivir. ¿Dónde queda la educación de los sentimientos? Somos, ante todo, inteligencia afectiva. ¿Dónde la educación de las relaciones sociales? ¿Dónde la educación en valores humanos? ¿Dónde la educación de la religiosidad? ¿Dónde la maduración de la fe, que debe ser compromiso personal? Y personal debe ser la forma en que cada uno siga a Jesucristo.

\subsubsection{Aprender a desaprender}

96. San AGUSTíN, Sermones 169, 18.

97. ÍD, Tratado sobre el Evangelio de san Juan 63, 1. Cf. José VEGA, La vocación agustiniana. El proyecto filosófico-monástico-sacerdotal de san Agustín, edic. cit., 101-106. 
En este aprender a aprender hay un aspecto que no debemos pasar por alto, quizá el más difícil, aprender a desaprender. Aprender, con frecuencia, es añadir conocimientos a los que ya se tienen, acumular saberes que en nada modifican las actitudes y comportamientos habituales. Esto es engordar culturalmente, no es mejorar, progresar, crecer como persona. Aprender debe ser también, y no en último lugar, cuestionarse lo que uno sabe y los comportamientos que tiene, ratificarse en ellos o rectificarlos o eliminarlos: desaprender. En todo caso, el resultado de un buen aprendizaje será siempre una visión nueva de la realidad, un nuevo modo de ser hombre. Ortega y Gasset escribió que hay que " aprender a des-pensar los viejos conceptos", a liberarse de ellos y a forjar otros nuevos ${ }^{98}$. La educación permanente exige estar poniendo siempre a prueba los conocimientos y comportamientos adquiridos

Hay en la sociedad usos y costumbres inveterados, multiseculares. Vienen nuevas leyes, pero los antiguos usos siguen ahí. El Concilio de Trento prohibió los matrimonios clandestinos, pero hasta bien entrado el siglo XVII siguió habiéndolos. Los cambios sociales comienzan por afectar la superficie, es lo único que se puede cambiar por decreto; pero las profundidades de la sociedad, la intrahistoria, que decía Unamuno, siguen un ritmo muchísimo más lento. Como uno es el oleaje del mar en la superficie y otro el de las corrientes abisales. Lo mismo sucede en el individuo. Comportamientos y creencias aprendidos en la infancia y adolescencia siguen ahí, actuando en el subconsciente, a pesar de que consciententemente hayan sido sustituidos por otros. Están ahí, convertidos casi en fisiología, y no hay modo de desarraigarlos. Por eso, hoy se habla de la necesidad de desaprender, de desescolarizar la sociedad, lo cual no quiere decir que haya que eliminar las escuelas, sino que la sociedad escolarizada tiene que aprender a rectificar muchos de los esquemas recibidos y ser receptiva a los nuevos conocimientos. La educación ecuménica, por ejemplo, exige un lento desaprendizaje de comportamientos seculares mutuamente recelosos y hostiles ${ }^{99}$.

Hoy se habla mucho de inculturar la fe (tarea que se presenta de manera especialmente apremiante en Occidente por el abismo que hay entre la cultura actual y las expresiones tradicionales de la fe), es decir, de conceptualizarla y formularla desde nuestros días; pero las viejas visiones siguen ahí, correosas e indestructibles, a veces incluso en quienes han

98. En torno a Galileo, edic. cit., 181.

99. Cf. Jacques NICOLE, Désapprendre pour apprendre. Vers une formation théologique oecumenique, en Études Théologiques et Religieuses 69 (1994) 549-557. 
hecho suyas las nuevas fórmulas. O se actúa de acuerdo con la nueva visión en unos comportamientos y con la antigua en otros. Ya nadie cree que Dios envíe la lluvia o la retire, pero en tiempo de sequía pertinaz se vuelve a las antiguas rogativas. Llueva o no, siempre se encontrarán explicaciones, por supuesto contra la ciencia en la que habitualmente estamos. Tenemos que desaprender muchas imágenes que aprendimos sobre Dios. Por ejemplo, hoy es intolerable la idea de que habrá un juicio final, en el que Dios sacará a plaza pública hasta los más íntimos detalles de la vida privada de cada uno. ¡Qué Dios más absurdo, del que decimos que nos ama! Esto sería una violación de la intimidad, que hoy rechazamos sin contemplaciones. No la querríamos ni para nuestros enemigos. "Vehicular la imagen de un Dios severo que nos juzgará sobre el amor es una perversión. Esto nos hace pensar que Dios, que nos juzga, en el fondo no nos ama. Estas representaciones del juicio hacen la fe inhabitable. Desaprender estas representaciones es mostrar cómo el cristianismo evangelizó la idea de sanción final afirmando precisamente que tenemos un abogado -iy qué abogado!- ante Dios, que, para colmo, no lleva cuenta de nuestros pecados, nos ama y perdona"100. Pero el cristianismo posterior olvidó esta evangelización cristiana primitiva de la idea de un balance, de una sanción al final de la vida, presente en todas las culturas y religiones, y volvió a la idea, extraña al Evangelio, de un juicio espantoso, acompañado de gran aparato cósmico, que hará temblar el mundo y empavorecerá las conciencias. Dies illa, dies irae. A los predicadores del pasado, muy especialmente a los del Barroco, les entusiasmaba esta idea del juicio. ¿Cuándo desaparecerá de nuestro horizonte social y de la vida de tantísimos cristianos que siguen creyendo en tan terrorífico disparate? Los ejemplos podrían multiplicarse.

\subsubsection{Centinela, alerta}

Aprender a aprender es mantenerse, aunque los años avancen, joven de espíritu, receptivo, innovador, empeñado en alumbrar formas nuevas de vida, más dignas, más esperanzadas y estimulantes. Es ser capaz, pese a los años, de disfrutar de la vida y participar en ella. Mientras haya vida, hay que hacerla, mejorarla. "Pienso hacer como el zapatero que tira [estira] el cuero con los dientes hasta que le hace llegar donde él quiere", dice Sancho101. "Se abren ante las personas de nuestra época lo que podríamos llamar los cursos superiores de la educación sentimental, que no tiene por

100. André Fossion, Evangéliser la liberté (Table ronde...), en Lumen Vitae 51 (1996) 97. 
qué terminar. Se trata, no lo olvidemos, de buscar la perfección de la vida y el incremento de la ilusión. Se ha logrado en nuestro tiempo la prolongación de la vida biológica; hay que completarla con la prolongación, acaso la intensificación, de la vida biográfica. Sin que la muerte al ojo estorbo sea, diría el capitán Francisco de Aldana"102.

\section{LA COMUNIDAD EDUCATIVA}

Comunidad no viene de común-unión como se lee en libros piadosos sino del latín communitas, que a su vez viene de com-munis. Munis es el que cumple un deber, el que lleva una carga. Communis es el que comparte una carga, un deber ${ }^{103}$. El DRAE le asigna, entre otros, estos significados: "Conjunto de personas vinculadas por características o intereses comunes [...]. Junta o congregación de personas que viven bajo ciertas constituciones o reglas, como los conventos, colegios, etc."104. "Asociación de personas que tienen intereses comunes [...]. Conjunto de los individuos de una orden religiosa que viven en un mismo convento"105.

El conjunto de personas que se asocian con intereses comunes forman una comunidad: comunidad de vecinos, de regantes, de fabricantes de orujo... El conjunto de personas que trabajan en un centro educativo forman la comunidad educativa. Las une o las debe unir un interés común: la buena marcha del centro. Desde Alfonso el Sabio, la Universidad era la comunidad de maestros y discípulos. De ahí la gran participación que se daba a los estudiantes en las universidades medievales y en las del Siglo de Oro, a diferencia de la Universidad posterior de corte napoleónico. Hoy se ha extendido esta participación a toda la comunidad educativa. A todos los integrantes de una comunidad escolar les une un proyecto educativo común.

Este proyecto exige para su buena realización que las personas en él implicadas superen sus relaciones laborales y profesionales y las personali-

101. Miguel de CERVANTES, Don Quijote de la Mancha, edic dirigida por Francisco Rico, Instituto Cervantes / Crítica, Barcelona 1998², $2^{\text {a }}$ p. , LIX, 1108.

102. Julián MARÍAS, La educación sentimental, Alianza Editorial, Madrid 1992, 252.

103. A. ERNOUT - A. MEILLET, Dictionnaire étymologique de la langue latine, Editions Klinkcsieck, Paris $1974^{4}$, s. v. munis.

104. REAL ACADEMIA ESPAÑOLA, Diccionario de la lengua española, Madrid $2001^{22}$, s. v. comunidad.

105. María MOLINER, Diccionario de uso del español, Editorial Gredos, Madrid $1998^{2}$, s. v. comunidad. 
cen. Relaciones personales en el trabajo y en la fiesta, en el diálogo y en el encuentro. Relaciones que exigen cauces adecuados en que puedan desarrollarse, pero más importante que las estructuras de relación es el espíritu que las anima, la vida que en ellas se manifiesta, lo que escapa a toda ley y reglamento. Con las mismas leyes, puede haber comunidades muy distintas. Puede haber en ellas vida o muerte. Para que una comunidad educativa tenga calidad se requiere que entre sus miembros haya estima mutua, aceptación, respeto, cordialidad, espontaneidad. Que no trabaje cada uno a su aire como si solo él existiera (en mi clase mando yo), sino en colaboración, sabiéndose agente de un proyecto común a cuyo servicio está. Que cada uno se entregue a su labor con tesón venciendo la propensión natural al abandono, al ir tirando, a cumplir el expediente.

La comunidad educativa que quiere alcanzar una altitud digna en su actividad está siempre en camino, en actitud de aprendizaje, abierta a todas las mejoras. No cerrada sobre sí misma, sino abierta a la realidad que la rodea, la próxima y la lejana; abierta al pensamiento actual, a las artes, a las innovaciones, a todo lo que ennoblezca y dignifique al hombre. La comunidad educativa no está hecha, se está haciendo, y se hace con la aportación de cada uno, o se queda sin hacer y se malogra; y cada uno se hace a si mismo al hacer la comunidad.

La comunidad educativa debe ser un espacio de vida en el que las personas se encuentren a gusto en su trabajo, estimuladas en sus diferencias armónicas y complementarias, realizadas en su vocación. Un espacio en el que los valores éticos -dignidad, igualdad y diferencia, libertad y obediencia, responsabilidad y corresponsabilidad, tolerancia, justicia, solidaridad y generosidad, paz, profesionalidad, amabilidad, respeto, gratitud, autoestima, buen gusto, valentía (la valentía de que aquí se habla nada tiene que ver con la guerra), amor...-106, la buena educación y los buenos sentimientos se enseñen en las aulas y sean aire que se respira y práctica espontánea con espontaneidad aprendida.

La comunidad educativa cristiana vive todo esto en el Señor. Lo primero, la práctica y enseñanza de los valores humanos, es absolutamente necesario, pero no suficiente. Con ello solo, le faltaría precisamente lo específicamente cristiano. Lo segundo solo, sin los valores humanos, la llevaría a la deshumanización, a una espiritualidad tránsfuga de la realidad terrena, tantas veces vivida en el cristianismo. La comunidad educativa

106. Cf. Victoria CAMPS, Los valores de la educación, Alauda / Anaya, Madrid 1994; ÍD., Virtudes públicas, Espasa-Calpe, Madrid 19932; ÍD., Qué hay que enseñar a los hijos, Plaza \& Janés, Barcelona 2000; AA. VV., La educación en valores, PPC, Madrid 1997. 
cristiana, arraigada en la tierra, asumiendo los valores humanos, tiene su estrella polar en el Señor, la señal levantada en alto (Jn 3, 13-15). Su ley es el amor, pero un amor a semejanza del de Jesús, un amor que es expansión del que de él recibe (Jn 1, 16), que tiene su origen en Dios. "Os doy un mandamiento nuevo: que os améis unos a otros; igual que yo os he amado, también vosotros amaos unos a otros. En esto conocerán todos que sois discípulos míos: en que os tenéis amor entre vosotros" (Jn 13, 34-35)107. Por este amor, la comunidad educativa cristiana se convierte en una comunidad fraterna, en una comunidad de hermanos que invocan al Padre común de todos como "Padre nuestro". En Él encuentra un impulso nuevo, superior, para el diálogo y la participación y la corresponsabilidad en la tarea común; una razón última y fundamental para vivir en amor y libertad en el servicio mutuo. "Los dones son variados, pero el Espíritu el mismo; las funciones variadas, aunque el Señor es el mismo; las actividades son variadas, pero es el mismo Dios quien lo activa todo en todos" (1 Co 12, 4-6). En la comunidad educativa cristiana, hay distintos ministerios, distintas funciones, distintos cargos (director, secretario, tutores, profesores...), pero todos, todos, al servicio de la comunidad para que todos sus miembros alcancen la edad adulta, la madurez, el desarrollo pleno.

La comunidad educativa cristiana no está cerrada sobre sí misma. Está en comunión con las otras comunidades cristianas, formando todas el Cuerpo de Cristo (Ef 4, 1-16; Rom 12, 4-8). Esta imagen del Cuerpo de Cristo a nosotros nos resulta una expresión gris, anodina. Nos evoca una estructura rígida, bien trabada, un organismo biológico, una máquina, aunque viviente. Pero la expresión original es riquísima para la espiritualidad. El cuerpo es la persona, la persona en su mismidad y en su relación con las otras. El Cuerpo de Cristo son las personas creyentes en Cristo, en su mismidad y en su relación con las otras que también creen en él. Según esta imagen, los creyentes están unidos al Señor y están unidos entre sí por los servicios mutuos que se hacen. Forman una comunidad perfectamente sintonizada: diferentes, pero unidos. Con esta imagen, se invita a cada uno a estar en su lugar y respetar el de los otros. Nadie está en el centro, ni siquiera el que preside, que es uno de tantos. Ni siquiera se le cita en primer lugar ${ }^{108}$. Una Iglesia bien distinta, por cierto, de la que nosotros tenemos. La historia no pasa en balde.

107. Cf. José VEGA, Sobre el "amor mutuo" de los cristianos, en Estudio Agustiniano 31 (1996) 79-117. 
En la comunidad educativa cristiana, la Palabra de Cristo se despliega con toda su fuerza, y unos y otros se educan mutuamente, enseñan y se dejan enseñar. "El mensaje de Cristo habite entre vosotros en toda su riqueza: enseñaos y aconsejaos unos a otros lo mejor que sepáís" (Col 3, 16). "Esmeraos en lo que favorece la paz y construye la vida común" (Rom 14,19 ), la casa de vuestras relaciones mutuas, que es la casa de Dios (Ef 2, 19-22), su templo santo, su morada de piedras vivas, el Sancta Sanctorum de la Nueva Alianza; hogar confortable, cómodo, atopadizo, en el que cada uno se encuentre feliz. "Como buenos hermanos, sed cariñosos unos con otros rivalizando en la estima mutua" (Rom 12,10).

¿Por qué nos costará tanto comprender este giro radical que Jesucristo dio a la idea que las religiones tenían de la presencia de Dios? Ya no se le adora en los templos, ni en Jerusalén ni en Garizín ni en ningún otro templo de la tierra. Tampoco en el templo de la naturaleza, aunque otra cosa hayan dicho los espirituales cristianos. La revelación judeocristiana sacó a Dios de la naturaleza y le situó en la historia. La teología natural no tiene razón de ser. Las cinco vías para probar la existencia de Dios no prueban nada. Contemplando la naturaleza, la belleza de las criaturas, una noche estrellada, por ejemplo, se puede llegar hasta el borde mismo del misterio, llenarse de asombro y de preguntas; llegar incluso hasta lo divino como fundamento de la realidad y experimentar un sentimiento religioso, pero de ahí no hay modo de pasar. Dios, al menos el Dios de los cristianos se queda siempre fuera. Cabría preguntar a los que afirman a Dios desde la belleza y bondad de las criaturas dónde dejan la fealdad y la maldad de las mismas, el sufrimiento de la humanidad, que tantos ateos hace, y dónde los estragos que la misma naturaleza causa. Si "Dios es amor" (1Jn 4, 8), ese es el lugar para buscarle y tener experiencia de Él en la oscuridad de la fe. "Pues el Padre busca hombres que le adoren en espíritu y lealtad" (Jn 4, 23-24). "Por ese cariño que os tengo os exhorto, hermanos, a que ofrezcáis vuestra propia existencia [vuestro cuerpo, literalmente: vuestra persona, vuestras relaciones mutuas] como sacrificio vivo, consagrado, agradable a Dios, como vuestro culto auténtico" (Rom 12,1). "Uno que me ama cumplirá mi mensaje y mi Padre le demostrará su amor: vendremos a él y nos quedaremos a vivir con él" (Jn 14, 23). Son algunos de los muchos textos que nos hablan de esta casa de Dios que son las relaciones mutuas de cariño y colaboración.

108. Cf. Philippe BACQ, Rêver d'Église, en Lumen Vitae 51 (1996) 27. 
La espiritualidad tradicional nos enseñó a encontrar a Dios en la oración y en los sacramentos, a visitar a Jesucristo en el sagrario. Está bien, pero hay en nuestra formación un gran vacío, un hueco que tenemos que llenar meditando estos textos del Nuevo Testamento, que nos dicen que con nuestras relaciones de servicio recíproco nos vamos construyendo mutuamente como casa de Dios; que en ellas vive Dios. Esta es la inhabitación del Espíritu santo: no dentro del creyente sino fuera, en sus relaciones de ayuda y colaboración. "La liturgia del amor mutuo reemplaza definitivamente la de la primera Alianza hecha de ritos y sacrificios" 109 ¡¡Cómo cambiarían nuestras comunidades si fuésemos personas maduras en la fe, creyentes en esta presencia de Dios en nosotros cuando mutuamente nos amamos! ¿Sueño o realidad? Intentemos que sea realidad. "!Gálatas estúpidos!, dice san Pablo en su carta de la libertad cristiana, ¿Quién os ha embrujado? ¡Después que ante vuestros ojos presentaron a Jesucristo en la cruz! [...] ¿Empezastéis por el espíritu para terminar ahora con la materia?" (Gál 3,1). ¡Ojalá no se nos puedan dirigir también a nosotros estos reproches!

El Concilio Vaticano II, entre tantas novedades como trajo, redescubrió la predilección de Jesús por los marginados. Los marginados en una comunidad educativa son, y en ello se insiste hoy día, los alumnos menos dotados no solo intelectualmente, los más desfavorecidos, los alumnos con problemas. A ellos hay que consagrarles una dedicación especial. Esta es la primera opción por los pobres en una comunidad educativa cristiana. Los marginados son también los que no pueden estudiar por falta de medios, tanto en el entorno próximo como en el lejano. Una comunidad educativa cristiana no puede ser ajena a estos problemas. La promoción de la justicia social y otras justicias debe ser en ella tarea primordial ${ }^{110}$.

En las comunidades educativas de las Órdenes religiosas, es cada día más frecuente la presencia de laicos en el profesorado. Digamos, en fidelidad a la verdad, que hasta ahora lo han sido por necesidad, no por reconocimiento de su vocación cristiana, llamados a trabajar en la misión de la Iglesia en colaboración con los sacerdotes, a pesar de que esta ya había sido descubierta por teólogos como Congar. Como en tantos momentos de la historia, hagamos de la necesidad virtud. Promovamos en las comunidades educativas de las Órdenes religiosas la participación de los laicos, varones y mujeres. ¡Manes de la tradición, estaos quedos! La Lumen gentium y

109. ÍD., íb., íb., 35.

110. Cf. Julián MARÍAS, La justicia social y otras justicias, Espasa-Calpe. Madrid 1979. 
el desarrollo de la teología posterior nos invitan a ello. Los laicos admitidos en una comunidad educativa cristiana no son un apéndice. Son miembros de la misma exactamente igual que los religiosos. ¿Se les puede excluir de las funciones de responsabilidad? ¿Qué comunidad cristiana sería esa? ¿O es que los religiosos no pueden estar a las órdenes de un laico? Lo único que se les debe exigir es competencia para el cargo y fidelidad al proyecto de la Institución. Los jesuitas, en la Congregación 34, n 13 , decidieron darles cargos de responsabilidad, y expresamente dijeron que, en tal caso, los jesuitas estarán bajo la dirección de los laicos, comprometiéndose al mismo tiempo a madurar con ellos en la fe e introducirlos en el espíritu y estilo de su Institución. Es este uno de los signos de los tiempos. No vivamos de espaldas a él.

José VEGA

Estudio Teológico Agustiniano

Valladolid 